\title{
A Divalent PAMAM-based Matrix Metalloproteinase/Carbonic Anhydrase Inhibitor for the Treatment of Dry Eye Syndrome
}

B. Richichi, ${ }^{\dagger[\mathrm{a}]}$ V. Baldoneschi, ${ }^{[a]}$ S. Burgalassi, ${ }^{[b]}$ M. Fragai, ${ }^{\dagger[\mathrm{a}][\mathrm{c}]}$ D. Vullo, ${ }^{[a]}$ A. Akdemir, ${ }^{[\mathrm{d}]}$ E. Dragoni, ${ }^{[a]}$ A. Louka, ${ }^{[c]}$ M. Mamusa, ${ }^{[a]}$ D. Monti, ${ }^{[b]}$ D. Berti, ${ }^{[a]}$ E. Novellino, ${ }^{[\mathrm{e}]}$ G. De Rosa, ${ }^{[e]}$ C. T. Supuran, ${ }^{*[\mathrm{f}]}$ and C. Nativi ${ }^{*[\mathrm{a}][\mathrm{c}]}$

[a] Dr. B. Richichi, Ms. V. Baldoneschi, Prof. M. Fragai, Dr. D. Vullo, Dr. E. Dragoni, Ms. M. Mamusa, Prof. D. Berti, Prof. C. Nativi

Department of Chemistry "Ugo Schiff"

University of Florence

via della Lastruccia,3-13; 50019 Sesto F.no (FI) - Italy

E-mail: cristina.nativi@unifi.it

[b] Prof. S. Burgalassi, Dr. D. Monti

Department

University of Pisa

via Bonanno, 33; 56126 Pisa - Italy

[c] Prof. M. Fragai, Ms. A. Louka, Prof. C. Nativi

CERM

University of Florence

via Sacconi, 6; 50019 Sesto F.no (FI) - Italy

[d] Prof. A. Akdemir

Department of Pharmacy

Faculty of Pharmacy, Bezmialem Vakif University

Address 2 Faith, Istambul - Turkey

[e] Prof. E. Novellino, Prof. G. De Rosa

Department of Pharmacy

University of Napoli "Federico II"

via Montesano, 49; 80131 Napoli - Italy

[f] Prof. C.T. Supuran

NEUROFARBA Department

University of Florence

via U. Schiff, 6; Sesto F.no (FI) - Italy

$\uparrow$ These authors contribute equally to the present work 


\begin{abstract}
Synthetic sulfonamide derivatives are a class of potent Matrix Metalloproteinase Inhibitors (MMPI) potentially useful to treat diseases related to an uncontrolled expression of these enzymes. The lack of selectivity of the large majority of those inhibitors, leading to the inhibition of MMPs in tissues different than the targeted one, dramatically reduced the therapeutic interest for MMPIs. The recent development of efficient drug delivery systems, allowing the transportation of a selected drug to its site of action, opened the way to new perspectives in the use of MMPIs. In this manuscript, the PAMAM-based divalent dendron 3, presenting two sulfonamidic residues, was synthesized. This nanomolar inhibitor is able to bind the catalytic domain of two MMPs as well as the transmembrane human Carbonyc Anhydases (hCAs) XII, present in the eye and considered an antiglaucoma target. In the animal model of experimental dry eye, no occurrence of dotted staining in eyes treated with $\mathbf{3}$ was observed, indicating no symptom of corneal desiccation.
\end{abstract}

\title{
Introduction
}

The widespread family of matrix metalloproteinases (MMPs) is constituted by calcium-dependent zinc-containing peptidases also known as matrixins.[1] MMPs exert fundamental physiological roles such as tissue remodelling and cellular matrix degradation but, if pathologically over-expressed, trigger a variety of severe disorders including atherosclerosis, heart failure and cancer.[2]

For many years, the development of MMPs' synthetic inhibitors (MMPIs) represented an eagerly pursued strategy to regulate the abnormal expression of MMPs; however, the disappointing clinical trials' outcomes convinced researchers to reconsider this approach.

Similar binding domains, showing the common property of adapting the binding pocket to the ligand shape, characterize all MMPs within the family. In addition, the very large majority of the inhibitors reported at present, features low bioavailability and reduced solubility in physiological media. These hallmarks, accounting for a lack or poor selectivity of all the inhibitors developed so far and for the induction of undesired in vivo side effects, made MMPs unreliable pharmaceutical targets and impaired the development of synthetic MMPIs as drugs.

Recently, structural insights into the X-ray structure of the catalytic domain of MMP-12 in the presence of the nanomolar inhibitor NNGH[3] enabled to perform structural modifications of the skeleton of NNGH to obtain a new family of non-toxic MMPIs, A, soluble in water and that maintains a high affinity vs. MMPs[4,5] (Figure 1). 


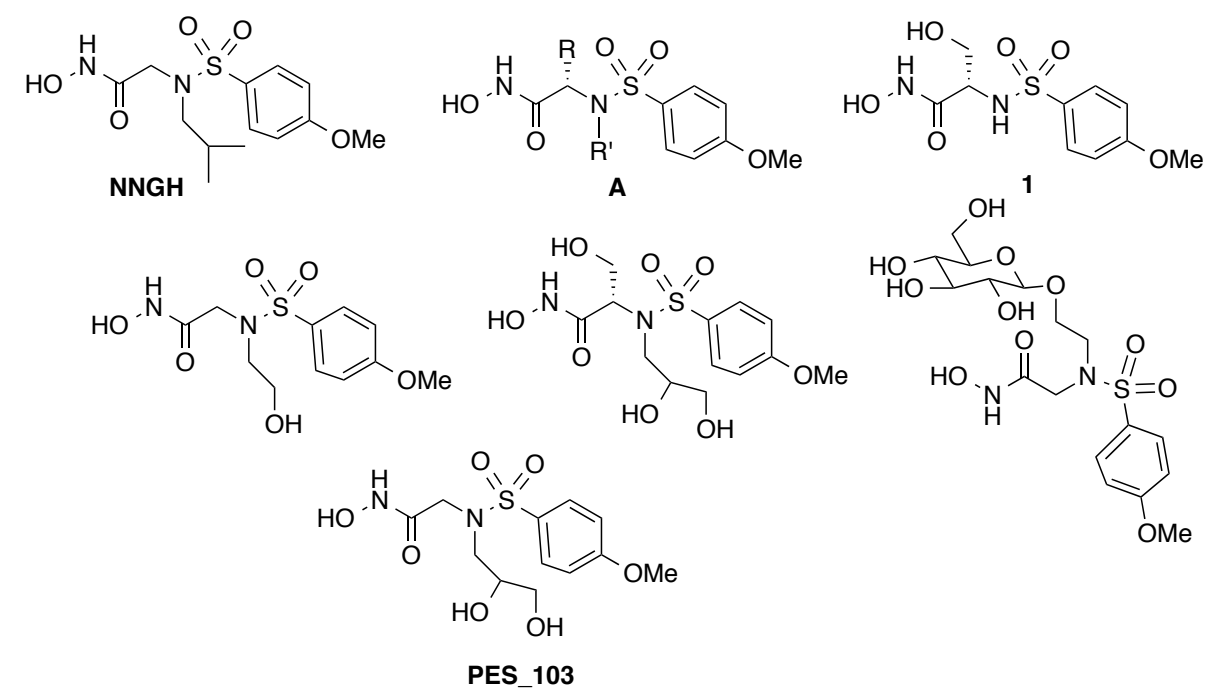

Figure 1. Structure of NNGH and of water-soluble MMPIs

Relying on the properties of these attracting molecules, we tried to overcome the drawback represented by the lack of selectivity of synthetic MMPIs focussing our attention on diseases mediated by the local uncontrolled activity of MMPs and which could be treated with topical administration of selected inhibitors.

In the uncontrolled breakdown of extracellular matrix, MMPs play a harmful role in the onset and continuous damage of ocular surface. 6 In particular, the gelatinase MMP-9 is the most important MMP on ocular surface; its concentration is notably high in tears of patients with the dry eye syndrome (DES) also known as keratoconjunctivitis sicca (KCS) [6]. DES is a multifunctional disorder in which inflammation plays a relevant role [7] and includes aqueous tear deficiency and the excessive tear evaporation. Ocular stress due to desiccation was demonstrated to increase the expression of MMP-9 in a murine model. [8]. MMP-9 is active in degrading the components of the corneal epithelial basement membrane, largely compromising the corneal epithelial desquamation. [9].

For the treatment of DES and of ocular diseases in general, the topical administration of drugs remains the easiest route and the preferred by patients. In the treatment of DES symptomatic remedies are largely used; alternatively, non-specific anti-inflammatories can be administered. [10] Recently, [11] we developed a non-symptomatic approach for the treatment of DES that relies on the inhibition of MMP-9 by a water-soluble small molecule, namely PES_103. [5] In vitro and in vivo tests demonstrated: i) the efficacy of PES_103 in the treatment of DES on a mice model of reduced lacrimation and ii) the lack of corneal cytotoxicity. [11]

In order to develop an effective treatment for DES, it is mandatory taking into account that the absorption of drugs topically applied on the eyes is generally very poor because of anatomical and physiological barriers. [10] In particular: a) the epithelium, the outermost layer of the cornea, hampers 
drug penetration and b) lacrimation, induced by standard eye drops application on the eye surface, causes dilution of the drug and drainage.

Successful delivery systems, specifically designed for topical ocular administration, have recently been reviewed. [12,13] Among them, PAMAM dendrimers [14] have been evaluated and preliminary results showed that PAMAM complexes increased the residence time and corneal penetration of ocular dugs like pueranin [15] in rabbit animal models with respect to the free drug solutions. Other promising data referring to dendrimers as suitable ophthalmic vehicles, also showing their bioadhesive properties on corneal surface, [16] convinced us to chemically link the nanomolar, watersoluble inhibitor 1 (see Figure 1) to the PAMAM-based dendron (G0) 2 with the aim to obtain a potential new drug for DES treatment (Figure 2).

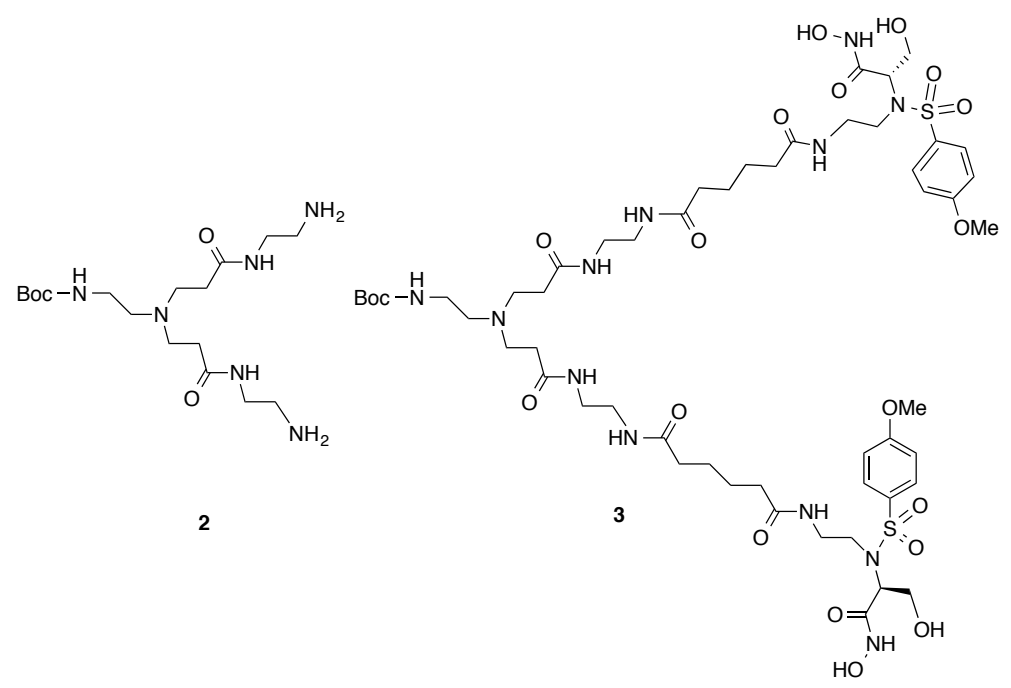

Figure 2. Structure of the PAMAM-based dendron (G0) 2 and the divalent inhibitor 3.

In this paper, we therefore report on the synthesis of the PAMAM-based divalent inhibitor $\mathbf{3}$, and on its binding affinity vs. MMP-9 and -12 (macrophage elastase) and on its efficacy for the nonsymptomatic treatment of DES in a rabbit model. In addition, the derivative $\mathbf{3}$, presenting two residues of the MMPs' inhibitor 1, also prompted the investigation of a possible simultaneous interaction with the catalytic binding site of two MMPs to form a ternary complex. Due to the strong structural similarity among MMPs and Carbonic Anhydrases (CAs, EC 4.2.1.1), metalloenzymes physiologically expressed in the eye, we also assessed the binding properties of $\mathbf{3}$ to all catalytically active human (h) CA isoforms hCA I- hCA XIV.

\section{Results and Discussion}




\section{Preparation of the PAMAM-based inhibitor 3}

The inhibitor 1 (see Figure 1) is an analogue of PES_103, structurally simpler but preserving nanomolar affinity for an array of MMPs.[5] To obtain the desired PAMAM-based inhibitor 3, a linker of nine atoms (10 $\AA$ length) was introduced on the sulphonamidic nitrogen of $\mathbf{1}$ in order to allow the inhibitor to correctly reach the binding pocket of the selected MMP. The serine methylester 4, presenting the hydroxyl group of the lateral chain protected as tertbutyl ether, was thus reacted with 4-methoxybenzensulfonyl chloride and catalytic N,N'-dimethylaminopyride (DMAP), at rt in dichloromethane as solvent, to give the corresponding sulphonamide 5 (90\%). Sulphonamide 5 was then reacted with N-Cbz-ethanolamine 6 under Mitzunobu conditions. After one night at room temperature, compound 7 was isolated in $82 \%$ yield. Subsequent removal of the tertbutyl protecting group (trifluoroacetic acid, 2 hours, rt, 8, 85\%) and of the Cbz group (H2, $\mathrm{Pd} / \mathrm{C}, 2 \mathrm{~h}, \mathrm{rt}$ ) afforded the compound 9 in 90\% yield which, in turn, was reacted with the linker $\mathbf{1 0}$ (see Supporting Information). The reaction was run in dry DMF as solvent at $\mathrm{rt}$ and in the presence of Nmethylmorpholine (NMM) to give the sulphonamide 11, suitably activated to react with the PAMAM-based dendron (G0) 2 (see Supporting Information). A solution of 11 in DMF was treated at rt with $\mathbf{2}$ and NMM; after two hours the divalent derivative 12 was isolated and purified by column chromatography on silica gel (72\%). The final treatment of 12 with hydroxylamine at $60{ }^{\circ} \mathrm{C}$ for two hours afforded, after purification by HPLC, the desired PAMAM-based divalent inhibitor 3 in $30 \%$ yield.

\section{Binding assay}

MMPs - The affinity of the PAMAM-based divalent inhibitor 3 toward MMP-9 was firstly evaluated by fluorimetric assay. The Ki value obtained for 3 against MMP-9 was $289 \mathrm{nM}(+/-53 \mathrm{nM})$, that is satisfying, even though in the high nanomolar range. We then moved to investigate the ability of the dendron 3 to bind simultaneously the catalytic domains of two distinct MMPs. In NMR experiments the chemical shift of signals is a sensitive indicator of protein-ligand interactions, therefore NMR binding studies were run using the catalytic domain of MMP-12 as model to evaluate the binding mode of compound $\mathbf{3}$ with this widely studied and fully characterized member of the MMPs' family. The identification of the binding site was easily accomplished analyzing the chemical shift perturbation of the protein resonances in $1 \mathrm{H}-15 \mathrm{~N}$ HSQC spectrum after the addition of the bifunctional ligand 3 (Figure 3). As expected, the pattern of signals shift mainly concerns the residues of the active site (Figure 4) including some amino acids forming the S1' cavity. Since the binding of two MMP's catalytic domains to each hydroxamic residue of the divalent dendron 3 could be expected to occur upon the addition of a half equivalent of the inhibitor to the protein solution, $\mathrm{NH}$ 
resonances were also considered as possible probes to investigate the formation of a dendron mediated MMP dimer. However, the addition of the PAMAM-based divalent inhibitor 3 did not produce a sizable broadening of the NH resonances despite the large molecular weight of the expected complex (MW>35kDa). This puzzling result has tentatively been ascribed to the length of the dendron's arms that enable the two proteins to move independently in solution. [17,18] This hypothesis was supported by the analysis of the hydrodynamic radius of the catalytic domain of MMP-12 measured by dynamic light scattering analysis in solutions, in the presence or absence of a half equivalent of the dendron 3. Indeed, the Small Angle X-ray Scattering (SAXS) experimental value (see Supporting Information) of $24 \mathrm{~nm}$ found for the radius of gyration of the protein-ligand complex was in good agreement with the expected value of $22 \mathrm{~nm}$ calculated with the HydroNMR program [19] for the dimeric structural model composed by two MMP-12 catalytic domains placed in tight contact.

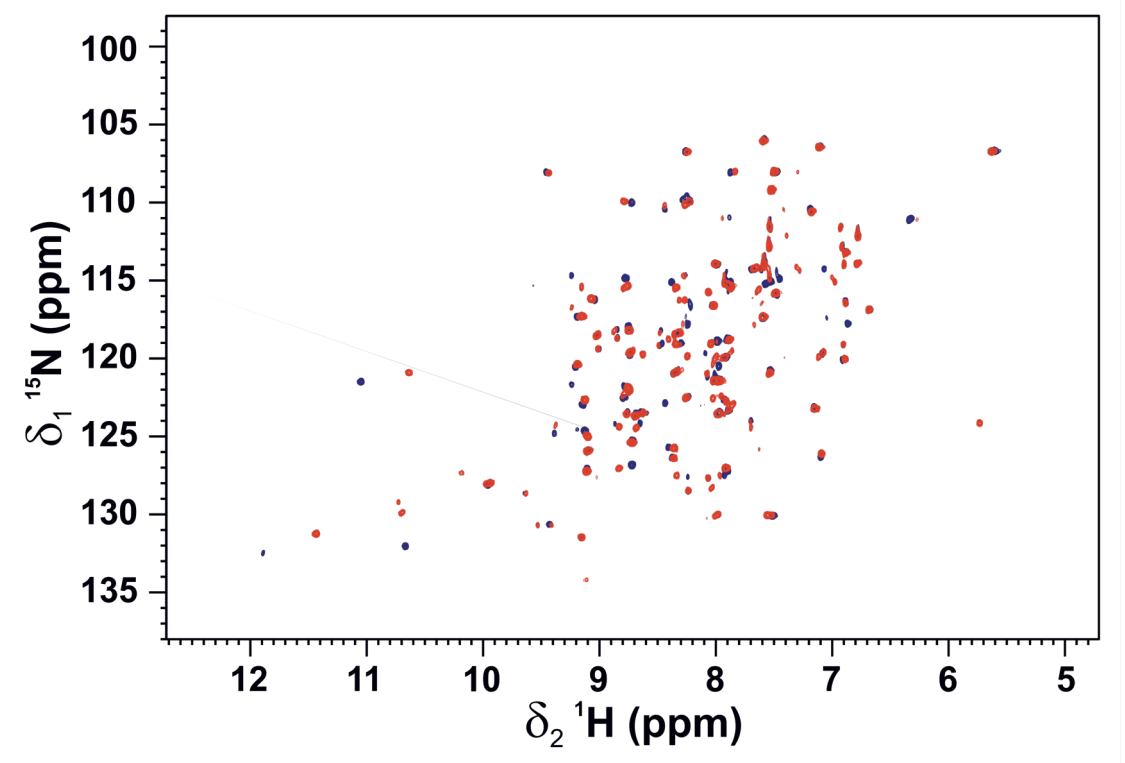

Figure 3. ${ }^{1} \mathrm{H}-{ }^{15} \mathrm{~N}$ HSQC spectrum of the catalytic domain of MMP-12 (blue), and in the presence of the PAMAM-based divalent inhibitor 3 (red). 


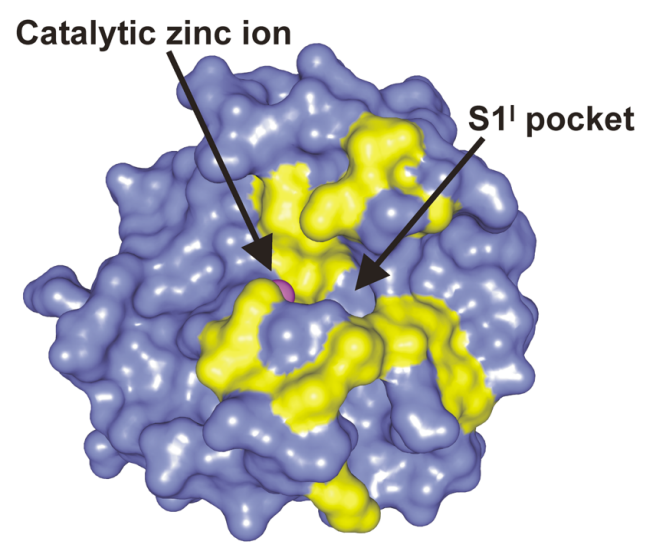

Figure 4. Surface representation of the catalytic domain of MMP-12. The residues showing significant chemical shift perturbation upon the addition of the PAMAM-based divalent inhibitor 3 (V162, D175, G178, I180, A182, H183, H196, D198, E199, A216, H218, E219, H228, S229, K233, F237, T239, Y240, Y241) are highlighted in yellow.

Carbonic Anhydrase - Hydroxamates were reported to act as CA inhibitors (CAIs) and to bind to the $\mathrm{Zn}$ (II) ion within the enzyme active site in a different manner compared to their binding to MMPs.[20] Thus, this type of compounds are indeed of interest to be investigated for their interactions with CAs, also considering the recent report that dendrimers functionalized with sulfonamide moieties are highly effective CAIs and also show anti-glaucoma effects in an animal model of the disease.[21] Here we investigated the interaction between hydroxamate $\mathbf{3}$ and all the catalytically active CA isoforms[22] by using a stopped flow $\mathrm{CO} 2$ hydrase assay (Table 1) as well as molecular docking of the inhibitor within several CA isoform active sites (Figures. 5 and 6).

Table 1: Binding studies of hydroxamate 3 versus hCAs. 


\begin{tabular}{lll}
\hline Isoform, $\mathrm{K}_{\mathrm{I}}, \mathrm{nM}^{[\mathrm{a}]}$ & $\mathbf{3}$ & AAZ (acetazolamide) \\
\hline hCA I & $>10000^{[\mathrm{b}]}$ & 250 \\
hCA II & $>10000^{[\mathrm{c}]}$ & 12 \\
hCA III & 3735 & 20000 \\
hCA IV & 845 & 74 \\
hCA VA & 74.5 & 63 \\
hCA VI & 65.3 & 11 \\
hCA VII & $>10000^{[\mathrm{d}]}$ & 2.5 \\
hCA IX & 28.9 & 25 \\
hCA XII & 65.1 & 5.7 \\
hCA XIII & 24.7 & 17 \\
hCA XIV & 338 & 41 \\
\hline
\end{tabular}

[a]Errors in the range of $\pm 10 \%$ of the reported values (data not shown, from 3 different assays).

[b] At $10 \mu \mathrm{M}$ an inhibition of $60 \%$ was registered.

[c] At $10 \mu \mathrm{M}$ an inhibition of $66 \%$ was registered.

[d] At $10 \mu \mathrm{M}$ an inhibition of $54 \%$ was registered.

Data of Table 1 (in which the clinically used sulphonamide acetazolamide (AAZ) was used as standard) show that hydroxamate $\mathbf{3}$ did not inhibit three cytosolic isoforms, among which the widely spread hCA I, II and the brain-associated CA VII, whereas the remaining eight hCAs were all inhibited, with inhibition constants ranging between $24.7 \mathrm{nM}$ and $3.73 \mu \mathrm{M}$. hCA III (muscle isoform) and the membrane-associated hCA IV and hCA XIV were the isoforms less sensitive to this inhibitor (KIs of $338-3735 \mathrm{nM}$ ) whereas all the remaining ones were inhibited with KIs $<100 \mathrm{nM}$. Thus, the mitochondrial hCA VA, the secreted isoform (in saliva and milk) hCA VI and the transmembrane hCA XII (present in the eye and considered as an antiglaucoma target),[23] were inhibited with KIs in the range of $65.1-74.5 \mathrm{nM}$. The tumor-associated hCA IX and the cytosolic hCA XIII were the two isoforms with the highest sensitivity to $\mathbf{3}$, with KIs of $24.7-28.9 \mathrm{nM}$. Although 3 is generally less effective than the sulfonamide AAZ, the fact that it does not inhibit the widely spread hCA I and II (present in high amounts in blood, gastro-intestinal tract and kidneys, and considered the main offtarget isoforms responsible for the side effects of these drugs) may be considered as a very favourable and salient feature of $\mathbf{3}$ as a CAI. [24-27] 
In order to rationalize these data of Table 1, we also performed some docking studies of $\mathbf{3}$ within the active sites of several isoforms. Compound 3 showed the highest inhibition for hCA XIII (24.7 nM) and hCA IX (28.9 nM), as mentioned above.

We expected that the hydroxamate nitrogen atom would interact with the $\mathrm{Zn} 2+$-ion and therefore we assigned a negative charge to the oxygen atom (R-CONHO-). Two poses have been identified for hCA XIII (Figure 5). The negatively charged oxygen atom approaches the $\mathrm{Zn} 2+$-ion (distance less than $2.5 \AA$ ) and could be thus able to participate in a coordinative interaction with the metal ion. The first pose forms a hydrogen bond between its hexanamide tail and the side chain of His136 (Figure 5A). The

ligand hydrophobic phenyl group and hexanamide tail are located close to Phe131 and additional hydrophobic interactions are formed with Ala135, Leu141, Leu198 and Leu204. The second pose orients its negatively charged oxygen atom at a similar location as the first pose but the hydroxamate carbonyl group forms an additional interaction with the $\mathrm{Zn} 2+$-ion (Figure 5B). One of the sulfonamide oxygen atoms forms a hydrogen bond to the side chain of Asn67 and hydrophobic interactions are formed mainly with Phe131.

Docking studies of $\mathbf{3}$ into the active site of hCA IX suggest that the hydroxamate group forms extensive contacts with the protein (Figure 6). The negatively charged oxygen atom interacts with the $\mathrm{Zn}^{2+}$-ion, the adjacent nitrogen atom forms a hydrogen bond to the side chain of His94 and the carbonyl group forms a hydrogen bond to with Thr199. One of the sulfonamide oxygen atoms forms a hydrogen bond with the side chain of Gln92 and the methoxy group forms a hydrogen bond with the side chain of His64. The hexanamide tail is flexible and water exposed.
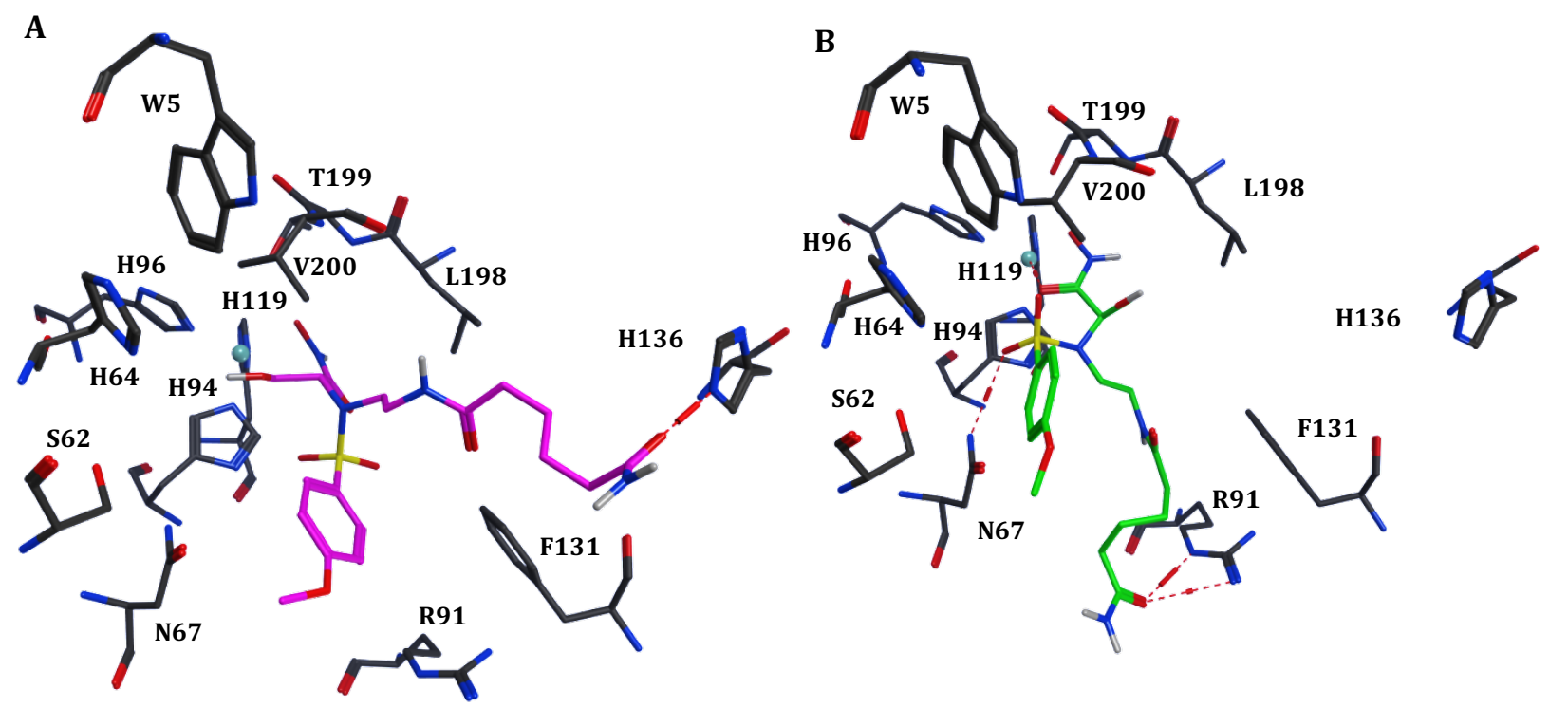
Figure 5. Docked pose of compound 3 in the binding pocket of hCA XIII (A, B). Hydrogen bonds and the interactions to the $\mathrm{Zn}^{2+}$-ion are indicated with red dashed lines. The $\mathrm{Zn}^{2+-}$ ion is indicated with a turquiose sphere.

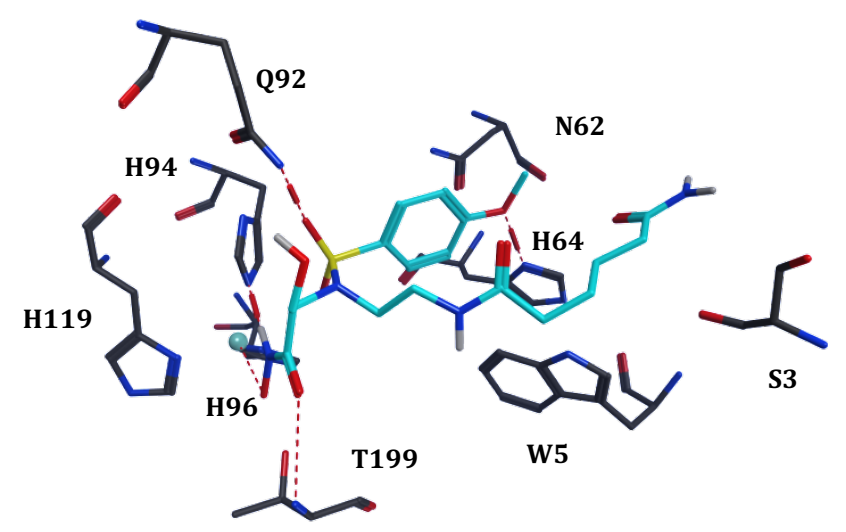

Figure 6. Docked pose of compound 3 in the binding pocket of hCA IX. Hydrogen bonds and the interactions to the $\mathrm{Zn}^{2+-i o n}$ are indicated with red dashed lines. The $\mathrm{Zn}^{2+}$-ion is indicated with a turquiose sphere.

\section{In vivo test.}

In order to assess the effectiveness of the PAMAM-based divalent inhibitor 3 to treat DES, an experimental dry eye on rabbits was induced by atropine sulphate solution ocular instillations. The Schirmer test scores (reported as millimeters of wet strip $3 \mathrm{~min}$ after insertion) obtained before (basal values) and after (dry eye) treatment with AS, and relevant to the treatment with the formulation under test, are reported in Figure 7. A decreased tear production ( $\mathrm{p}<0.05$, unpaired t test with Welch's correction) was observed since the third day after beginning of AS treatment: at this time the average Schirmer test score in dry eyes was reduced from $11.72 \pm 1.10 \mathrm{~mm}$ (basal value) to $9.75 \pm 0.25 \mathrm{~mm}$. Eyes treated with compound 3 showed greater scores with respect to control dry eyes at all experimental times, with values of about $14.5 \mathrm{~mm}$, and with statistically significant differences on the 3rd, 4th and 5th days of treatment ( $\mathrm{p}<0.05$, unpaired t test with Welch's correction). The slit-lamp examination of the fluorescein-stained corneas revealed no occurrence of dotted staining in treated eyes, indicating no symptom of corneal desiccation. Topical ocular administration of atropine causes to the animals few typical effects of antimuscarinic drugs such as mydriasis and cycloplegia, without producing significant side effects. Depression of saliva and tear production is usually the first sign of adverse systemic reaction and leads as a result the rapid onset of dry eye conditions. The effect is 
dose-related and maximized in albino eyes since it does not occur loss of drug for binding with the iris pigments. [28] Decreased tear production (evidenced by lower Schirmer test scores) and occurrence of dry spots on the corneal surface were observed on the second day of treatment, and remained constant (or increased, in the case of dry spots) over the five days of observation time. [29] Furthermore, anticholinergic-induced dry eye conditions are accompanied by increases in MMP-9 expression; [30] this model can therefore be usefully employed to evaluate the activity of 3 . Of note, this investigation points to $\mathbf{3}$ as an interesting new compound for artificial tear formulations able to restore the normal hydration degree on corneal surface already from the third day on treatment.

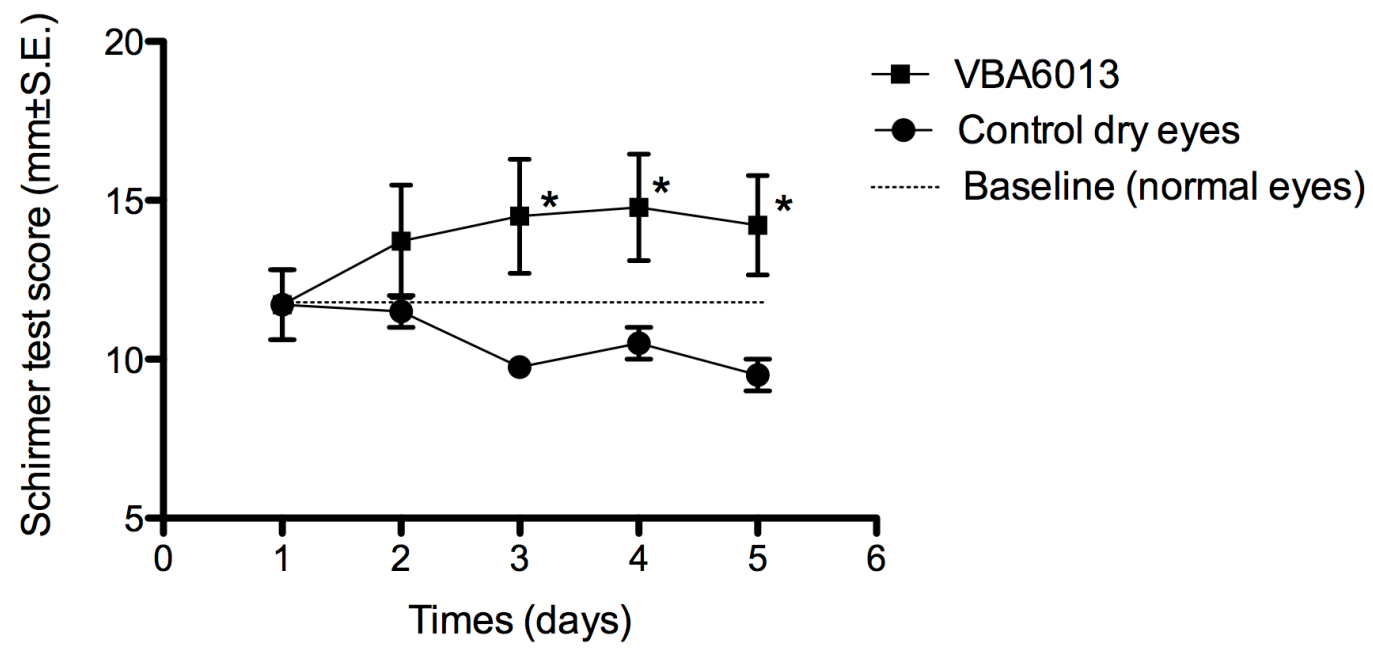

Figure 1. Schirmer test scores obtained using a solution of $\mathbf{3}$ in the rabbit dry eye model $(n=7)$. *Significantly different from control dry eye ( $<<0.05$, unpaired t test with Welch's correction).

\section{Conclusions}

The dramatic effects of the uncontrolled expression of MMPs well account for the efforts devoted to the development of new approaches aiming at the use of MMPIs in therapy. Recently, the development of efficient drug delivery systems allowing the transportation of a selected drug to its site of action has represented an important achievement for the administration of pharmaceutically active compounds. The modulating size and the chemical-physical properties of compounds like the PAMAM dendrimers make these macromolecules extremely attractive as ophthalmic drug delivery carrier. In an effort to overcome the too large spectrum of action of many effective MMPs inhibitors 
including compound $\mathbf{1}$, in this manuscript we linked, through a suitable spacer, two residues of the nanomolar MMP inhibitor 1 to the dendron 2 thus affording the divalent inhibitor $\mathbf{3}$. Merging the unique properties of the PAMAM architecture with the water solubility and high affinity of $\mathbf{1}$, a remarkable topical activity accompanied by a reduced systemic absorption was observed for the resulting dendron 3. The affinity, in high nanomolar range, of 3 vs. MMP-9 was assessed and we could also demonstrate that two MMP's catalytic domains are contemporary linked by the divalent inhibitor 3. This is the first example of a synthetic divalent inhibitor able to bind, with a nanomolar affinity, the catalytic domain of two different MMPs. Reasoning that the sulfonamidic residues characterizing 3 could also bind CAs, the affinity of 3 vs. hCAs was also evaluated. Our data showed that hydroxamate 3 did not inhibit three cytosolic isoforms, among which the widely spread hCA I, II and the brain-associated CA VII, whereas the remaining eight hCAs were all inhibited, including transmembrane hCA XII which is present in the eye and which is considered as an antiglaucoma target. Although $\mathbf{3}$ is generally less effective than the positive control, $\mathbf{A A Z}$, the fact that it does not inhibit the widely spread hCA I and II appears as a very favorable and peculiar feature of $\mathbf{3}$ as a CAI. The in vivo effectiveness and the therapeutic potential of the PAMAM-based inhibitor 3 was clearly demonstrated treating DES on rabbits, in an experimental model of dry eye which is accompanied by the increasing in MMP-9 expression. Eyes treated with compound 3 showed greater scores with respect to control dry eyes at all experimental times, corneas revealed no occurrence of damages in treated eyes, indicating no symptom of corneal desiccation. This investigation points to $\mathbf{3}$ as an interesting new compound for artificial tear formulations able to restore the normal hydration degree on corneal surface already from the third day on treatment.

Finally, even though the administration of high doses of drugs with high molecular weight is generally necessary to reach therapeutic concentrations, in the case of the divalent dendron 3 , the two residues of hydroxamic acid halves the amount of compound needed to be applied to the eyes. The divalence of the dendron, however, does not enhance the binding affinity vs. the selected MMP, which remains in the high nanomolar range towards the single catalytic domain. Further studies are in progress to evaluate specific formulations, like muco-adhesive gel, to improve the performance of $\mathbf{3}$.

\section{Experimental Section}

\section{Synthesis of the inhibitor $3^{\S}$}

To a stirred solution of $\mathbf{8}(1.0 \mathrm{mmol}, 581 \mathrm{mg})$ in dry DMF $(5.0 \mathrm{~mL})$, a solution of $2(0.5 \mathrm{mmol}, 194$ $\mathrm{mg})$ and NMM $(2.0 \mathrm{mmol}, 0.220 \mathrm{~mL})$ in dry DMF $(5 \mathrm{~mL})$ was added. The mixture was stirred at $\mathrm{rt}$ for $2 \mathrm{~h}$ then concentrated to dryness. The crude product was purified by column flash chromatography on silica gel $(\mathrm{CH} 2 \mathrm{Cl} 2 \mathrm{MeOH} 8: 1$ to $4: 1)$ to give 9 (0.72 mmol, 72\%). A suspension of $\mathrm{KOH}(630$ $\mathrm{mg}, 11.2 \mathrm{mmol})$ in $\mathrm{MeOH}(2.3 \mathrm{~mL})$ and a suspension of $\mathrm{NH} 2 \mathrm{OH} \cdot \mathrm{HCl}(670 \mathrm{mg}, 9.64 \mathrm{mmol})$ in $\mathrm{MeOH}$ 
$(4.5 \mathrm{~mL})$ were separately stirred for $10^{\prime}$ at $70^{\circ} \mathrm{C}$. Then the solution of $\mathrm{KOH}$ was added to the solution of $\mathrm{NH} 2 \mathrm{OH} \cdot \mathrm{HCl}$ and the mixture was stirred at $60^{\circ} \mathrm{C}$ for $10^{\prime}$. Then $9(50 \mathrm{mg}, 0.04 \mathrm{mmol})$ was dissolved in $0.680 \mathrm{~mL}$ of the freshly obtained suspension of $\mathrm{NH} 2 \mathrm{OH}$. The mixture was stirred at $\mathrm{rt}$ for $3 \mathrm{~h}$ then diluted with $\mathrm{MeOH}(5 \mathrm{~mL})$ and the solid was filtered off. The filtrate was concentrated to dryness to give $65 \mathrm{mg}$ of crude product, which was purified by HPLC (column Zorbax 300SB$\mathrm{C} 18,9.4 \times 250,5 \mu \mathrm{m}, \mathrm{H} 2 \mathrm{O}: \mathrm{MeOH} 50: 50)$ to give $3(0.012 \mathrm{mmol}, 30 \%)$ as a glassy solid.

\section{$\S$ See Supporting Information for full characterization}

\section{Protein expression and purification.}

The cDNA encoding the G106-G263 construct of the catalytic domain of MMP-12 was generated by a polymerase chain reaction (PCR) from an IMAGE consortium clone using two synthetic oligonucleotides as primers. The cDNA obtained was cloned into the pET21a (Novagen) using the restriction enzymes Nde I and Xho I (New England BioLabs). The expression vector encoding for wild-type cat-MMP-12 was transformed into competent Escherichia coli BL21, and colonies were selected for Ampicillin and resistance. Bacteria were grown in LB medium containing $100 \mu \mathrm{g} / \mathrm{ml}$ ampicillin in a shaker flask at $37^{\circ} \mathrm{C}$. Protein expression was induced with $0.5 \mathrm{mM}$ IPTG at an OD600 $=0.6$, and cell growth was continued for further 5 hours. For expression of $15 \mathrm{~N}$ cat-MMP-12 proteins, the bacteria were grown in minimal medium containing $15 \mathrm{~N}$ enriched (NH4)2SO4. Following expression, the enzyme was accumulated in the fraction of inclusion bodies. Cells were harvested by centrifugation and suspended in a buffer containing $25 \%$ sucrose, $50 \mathrm{mM}$ Tris- $\mathrm{HCl}(\mathrm{pH} 8), 0.1 \mathrm{M}$ $\mathrm{NaCl}, 0.2 \mathrm{M}$ EDTA, $1 \mathrm{mM}$ DTT. 5-10 mg of lysozyme were added to the resulting suspension and stirred for $15-20 \mathrm{~min}$. at $4{ }^{\circ} \mathrm{C}$. A buffer containing $2 \%$ Triton, $50 \mathrm{mM}$ Tris- $\mathrm{HCl}(\mathrm{pH} 8), 0.1 \mathrm{M} \mathrm{NaCl}$, 0.2 M EDTA, $1 \mathrm{mM}$ DTT was added and the suspension sonicated (7-8 30-seconds cycles) and centrifuged at $40000 \mathrm{rpm}$ for $20 \mathrm{~min}$. at $4{ }^{\circ} \mathrm{C}$. The pellet was resuspended in $6 \mathrm{M}$ Urea, $20 \mathrm{mM}$ Tris$\mathrm{HCl}(\mathrm{pH} 8)$ and centrifuged. The resulting inclusion bodies, containing the protein, were solubilized in a buffered solution with $20 \mathrm{mM}$ Tris- $\mathrm{HCl}$ and $8 \mathrm{M}$ urea at $\mathrm{pH} 8$. The protein was then purified with on cation exchange column Mono-S (Pharmacia) using a linear gradient of $\mathrm{NaCl}$ up to $0.5 \mathrm{M}$. The protein was refolded by using a multi-step dialysis against solution containing $50 \mathrm{mM}$ Tris- $\mathrm{HCl}$ $(\mathrm{pH}=7.2), 10 \mathrm{mM} \mathrm{CaCl} 2,0.1 \mathrm{mM} \mathrm{ZnCl} 2,0.3 \mathrm{M} \mathrm{NaCl}$ and decreasing concentration of urea (from 4 $\mathrm{M}$ up to $2 \mathrm{M}$ ). The last two dialysis were performed against solution containing $20 \mathrm{mM}$ Tris- $\mathrm{HCl}$ $(\mathrm{pH}=7.2), 10 \mathrm{mM} \mathrm{CaCl} 2,0.1 \mathrm{mM} \mathrm{ZnCl} 2,0.3 \mathrm{M} \mathrm{NaCl}$ and $200 \mathrm{mM}$ of hydroxamic acid. The protein solution was concentrated up to $5 \mathrm{ml}$ and purified by size exclusion chromatography using a High LoadTM 16/60 SuperdexTM 75 (Amersham Biosciences) and eluted with $20 \mathrm{mM}$ Tris pH 7.2, 10 $\mathrm{mM} \mathrm{CaCl} 2,0.3 \mathrm{M} \mathrm{NaCl}$, AHA $0.2 \mathrm{M}$. The eluted fractions were checked for purity on $15 \%$ gel by SDS-PAGE, and those containing the cat-MMP-12 protein were pooled and concentrated.

\section{CA inhibition assay.}

An Applied Photophysics stopped-flow instrument has been used for assaying the CA catalysed CO2 hydration activity.[31] Phenol red (at a concentration of $0.2 \mathrm{mM}$ ) has been used as indicator, working at the absorbance maximum of $557 \mathrm{~nm}$, with $20 \mathrm{mM}$ Hepes ( $\mathrm{pH} \mathrm{7.5)}$ as buffer, and $20 \mathrm{mM} \mathrm{Na} 2 \mathrm{SO} 4$ (for maintaining the ionic strength constant), following the initial rates of the CA-catalyzed $\mathrm{CO} 2$ hydration reaction for a period of 10-100 s. The $\mathrm{CO} 2$ concentrations ranged from 1.7 to $17 \mathrm{mM}$ for the determination of the kinetic parameters and inhibition constants. For each inhibitor at least six traces of the initial $5-10 \%$ of the reaction have been used for determining the initial velocity. The uncatalyzed rates were determined in the same manner and subtracted from the total observed rates. Stock solutions of inhibitor $(0.1 \mathrm{mM})$ were prepared in distilled-deionized water and dilutions up to $0.01 \mathrm{nM}$ were done thereafter with the assay buffer. Inhibitor and enzyme solutions were preincubated together for $15 \mathrm{~min}$ at room temperature prior to assay, in order to allow for the formation of the E-I complex. The inhibition constants were obtained by non-linear least-squares methods using PRISM 3 , as reported earlier for other dendrimers [21] and represent the mean from at least three different 
determinations. All CA isoforms were recombinant ones obtained in-house as reported earlier. [3234].

\section{In vivo tests.}

Animals. Non-anaesthetised, male, New Zealand albino rabbits, weighing 2.5-3.0 Kg (Pampaloni Rabbitry, Fauglia, Italy) were used and treated as prescribed in the publication "Guide for the Care and Use of Laboratory Animals" 35 All experiments conformed with the ARVO Resolution on the Use of Animals in Research: they were carried out under veterinary supervision, and after approval of the protocols by the Ethical-Scientific Committee of the University of Pisa. The animals were housed singly in standard cages in a room with controlled lighting, at $19 \pm 1{ }^{\circ} \mathrm{C}$ and $50 \pm 5 \%$ R.H., with no restriction of food or water. During the experiments, the rabbits were placed in restraining boxes to which they had been habituated, in a room with dim lighting; they were allowed to move their heads freely, and their eye movements were not restricted. Induction and treatment of dry eye conditions. The animals were preliminarily submitted to the Schirmer I test [36] and to slit-lamp examination of the corneal surface to verify the integrity of the corneal epithelium and the function of lachrymal system; then seven of them were treated as reported. [29] Briefly, the animals received in the lower conjunctival sac of both eyes $50 \mu \mathrm{l}$ of $1 \%$ atropine sulphate solution (AS) at 8.00 a.m., 1.00 p.m. and 6.00 p.m. Five minutes after each administration of AS they received in one eye $50 \mu 1$ of the formulation under study, while vehicle alone was administered in the control eye. All treatments were discontinued after 5 days. The Schirmer I test36 was performed 2, 3, 4 and 5 days after the first administration of AS, at 10.00 a.m. The test was performed on both eyes (nonanaesthetized) of all animals, by maintaining for $3 \mathrm{~min}$ a standardized test strip (Alfa Intes, Casoria, Italy) into the external third of the lower conjunctival fornix. The wetted length in millimeters of the strip was taken as the test score. After staining with fluorescein (Fluorets, Smith \& Nephew Pharmaceuticals Ltd, Romford, UK), the corneal surface was observed by slit-lamp biomicroscope fitted with a blue filter. The test was performed at 2.00 p.m., 3, 4 and 5 days after the first administration of AS. The occurrence of dotted staining, revealing the presence of dry spots on the ocular surface, was considered as a symptom of corneal desiccation.

\section{Acknowledgements}

We thank Ente Cassa di Risparmio di Firenze for financial support. Elettra Synchrotron is acknowledged for the access to the SAXS beamline, Heinz Amenitsch and Barbara Sartori (Elettra Synchrotron) for their technical support. Authors are grateful to the COST Action CM 1102.

Keywords: inhibitors; MMPs; Cas; dendrimer; dry eye 


\section{References}

[1] J. Cathcart, A. Pulkoski-Gross, J. Cao, Gene Dis. 2015, 2, 26 and refs cited therein.

[2] J.W. Skiles, N.C. Gonnella, A.Y. Jeng, Curr. Med. Chem. 2001, 8, 425 and refs cited therein.

[3] I. Bertini, V. Calderone, M. Cosenza, M. Fragai, Y.-M- Lee, C. Luchinat, S. Mangani, B. Terni, P. Turano, Proc. Natl. Acad. Sci, USA 2005, 102, 5334.

[4] V. Calderone, M. Fragai, C. Luchinat, C. Nativi, B. Richichi, S. Roelens ChemMedChem 2006, $1,598$.

[5] E. Attolino, V. Calderone, E. Dragoni, M. Fragai, B. Richichi, C. Luchinat, C. Nativi, Eur. J. Med.Chem. 2010, 45, 5919.

[6] C.S. De Paiva, R.M. Corrales, A.L. Villarreal, W.J. Farley, D.-Q. Li, M.E. Stern, S.C. Pflugfelder, Exp. Eye Res. 2006, 83, 526.

[7] Definition and Classification Subcommittee of the International Dry Eye Workshop, 2007.

[8] C.S. De Paiva, S. Chotikavanich, S.B. Pangelinan, J.D. Pitcher 3rd, B. Fang, X. Zheng, P. Ma, W.J. Farley, K.F. Siemasko, J.Y. Niederkon, M.E. Stern, D.Q. Li, S.C. Plugfelder, Mucosal Immunol. 2009, 2, 243.

[9] P. Aragona, M’A. Aguennouz, L. Rania, E. Postorino, M.S. Sommario, A.M. Roszkowska, M.G. De Pasquale, A. Pisani, D. Puzzolo, Ophtalmology 2015, 122, 62.

[10] J.G. Souza, K. Dias, T. Aparecida Pereira, D. Spuri Bernardi, R. F.V. Lopez, J. Pharm. Pharmacology 2013, 66, 507.

[11] M. Mori, E. De Lorenzo, E. Torre, M. Fragai, C. Nativi, C. Luchinat, A. Arcangeli, Basic Clin. Pharmacol. Toxicol. 2012, 111, 289.

[12] J. Vandervoort, A. Ludwig, Nanomedicine 2007, 2, 11.

[13] S.K. Sahoo, F. Dilnawaz, S. Krishnakumar, Drug Disc. Today 2008, 13, 144.

[14] E. Abbasi, S.F. Aval, A. Akbarzadeh, M. Milani, H.T. Nasrabadi, S.W. Joo, Y. Hanifehpour, K. Nejati-Koshki, R. Pashaei-Asl, Nanoscale Res. Lett., 2014, 9, 247.

[15] T.F. Vandamme, L. Brobeck, J. Control Release, 2005, 102, 23.

[16] N.K. Jain, U. Gupta, Exp. Opin. Drug Metabolism Toxicol., 2008, 4, 1035.

[17] I. Bertini, M. Fragai, C. Luchint, M. Melikian, E. Mylonas, N. Sarti, D.I. Svergun, J.Biol.Chem, 2009, 284, 12821.

[18] I. Bertini, V. Calderone, M. Fragai, R. Jaiswal, C. Luchinat, M. Melikian, E. Mylonas, D.I. Svergun, J. Am. Chem. Soc. 2008, 130, 7011.

[19] J. G. de la Torre, M.L.,Huertas, B. Carrasco, J. Magn. Reson. 2000, 147, 138.

[20] A. Di Fiore, A. Maresca, C.T. Supuran, G. De Simone, Chem. Commun. 2012, 48, 8838. 
[21] B. F. Carta, S.M. Osman, D. Vullo, A. Gullotto, J.Y. Winum, Z. AlOthman, E. Masini, C.T. Supuran, J. Med.Chem. 2015, 58, 4039.

[22] C.T. Supuran, Nat. Rev. Drug Discov. 2008, 7, 168.

[23] F. Fabrizi, F. Mincione, T. Somma, G. Scozzafava, F. Galassi, E. Masini, F. Impagnatiello, C.T. Supuran, J. Enzyme Inhib. Med. Chem. 2012, 27, 138.

[24] F. Carta and C.T. Supuran, Expert Opin. Ther. Pat. 2013, 23, 681.

[25] C.T. Supuran, Expert Opin. Ther. Pat. 2013, 23, 677.

[26] A. Scozzafava, C.T. Supuran, F. Carta, Expert Opin. Ther. Pat. 2013, 23, 725.

[27] E. Masini, F. Carta, A. Scozzafava, C.T. Supuran, Expert Opin. Ther. Pat. 2013, 23, 705.

[28] S.D. Jaanus, J.H. Carter in Clinical Ocular Pharmacology, (Eds J.D. Bartlett, S.D. Jaanus), Butterworth-Heinemann; 1995, pp. 167-182.

[29] S. Burgalassi, L. Panichi, P. Chetoni, M.F. Saettone, E. Boldrini, Ophthalmic Res. 1999, 31, 229.

[30] B. Xiao, Y. Wang, P.S. Reinach, Y. Ren, J. Li, S. Hua, H. Lu, W. Chen, PLoS ONE 10(1): e0115333 DOI:10.1371/journal.pone.0115333.

[31] R.G. Khalifah, J. Biol. Chem. 1971, 246, 2561.

[32] A. Maresca, C. Temperini, H. Vu, N.B. Pham, S.A. Poulsen, A. Scozzafava, R.J. Quinn, C.T. Supuran, J. Am. Chem. Soc. 2009, 131, 3057.

[33] A. Maresca, C. Temperini, L. Pochet, B. Masereel, A. Scozzafava, C.T. Supuran, J. Med. Chem. $2010,53,335$.

[34] J-Y. Winum, A. Maresca, F. Carta, A. Scozzafava, C.T. Supuran, Chem. Commun. 2012, 48, 8177.

[35] NIH Publication No. 92-93, revised 1985.

[36] O. Schirmer, Arch. Klin. Ophthalmol 1903, 56, 197. 


\section{Supporting Information}

Synthesis of compound $\mathbf{4}$

Pag. S2

Synthesis of compound $\mathbf{5}$

S2

Synthesis of compound 6

S3

Synthesis of compound 7

S3

Synthesis of compound $\mathbf{8}$

S4

Synthesis of compound 9

S4

Synthesis of compound $\mathbf{1 0}$

S5

In vivo tests - Formulation

S6

SAXS Experiments

S6 


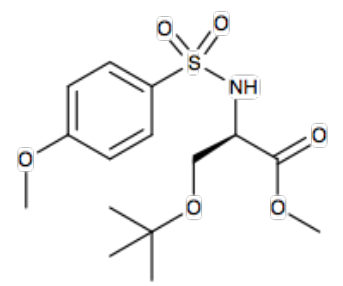

To a stirred solution of $\mathrm{H}-\mathrm{D}-\mathrm{Ser}(\mathrm{tBu})-\mathrm{OMe}$ hydrochloride $(2 \mathrm{~g}, 9.45 \mathrm{mmol})$ in $\mathrm{CH}_{2} \mathrm{Cl}_{2}(20.0 \mathrm{~mL})$, TEA (3.95 $\mathrm{mL}, 28.35 \mathrm{mmol})$ was added at $0^{\circ} \mathrm{C}$. After $30 \mathrm{~min}$ at $\mathrm{rt}$, the mixture was cooled to $0^{\circ} \mathrm{C}$ and DMAP $(0.115 \mathrm{~g}$, $0.94 \mathrm{mmol})$ and 4-methoxybenzenesulfonyl chloride $(1.95 \mathrm{~g}, 9.45 \mathrm{mmol})$ were added. The mixture was stirred at $\mathrm{rt}$ for $4 \mathrm{~h}$. After this time, the reaction mixture was diluted with $\mathrm{CH}_{2} \mathrm{Cl}_{2}(300 \mathrm{~mL})$ and washed with a saturated solution of $\mathrm{NH}_{4} \mathrm{Cl}(3 \times 30 \mathrm{~mL})$ and with a saturated solution of $\mathrm{NaCl}(2 \times 30 \mathrm{~mL})$. The organic phase was dried over $\mathrm{Na}_{2} \mathrm{SO}_{4}$ and concentrated to dryness to give $4(3.21 \mathrm{~g}, 99 \%)$ as a yellow solid. Mp: 65 $67^{\circ} \mathrm{C}$; ESI-MS $344.14[\mathrm{M}-\mathrm{H}]^{-} ;{ }^{1} \mathrm{H}$ NMR $\left(500 \mathrm{MHz}, \mathrm{CDCl}_{3}\right): \delta 7.79-7.76$ (AA' part of an AA'MM' system, $\left.J_{A M}=4.7 \mathrm{~Hz}, 2 \mathrm{H}\right), 6.96-6.93$ (MM' part of an AA'MM' system, $\left.J_{M A}=4.7 \mathrm{~Hz}, 2 \mathrm{H}\right), 5.39-5.38(\mathrm{bs}, 1 \mathrm{H}), 4.08-$ $4.05\left(\mathrm{~m}, 1 \mathrm{H}, \mathrm{CHCH}_{2} \mathrm{OtBu}\right), 3.85\left(\mathrm{~s}, 3 \mathrm{H}, \mathrm{PhOCH}_{3}\right), 3.68$ (A part of an $\mathrm{ABX}$ system, $J_{A B}=8.9 \mathrm{~Hz}, J_{A X}=3.2$ $\left.\mathrm{Hz}, \mathrm{CHCH}_{2} \mathrm{OtBu}\right), 3.55\left(\mathrm{~s}, 3 \mathrm{H}, \mathrm{COOCH}_{3}\right), 3.52$ (B part of an $\mathrm{ABX}$ system, $J_{B A}=8.9 \mathrm{~Hz}, J_{B X}=3.6 \mathrm{~Hz}$, $\mathrm{CHCH}_{2} \mathrm{OtBu}$ ), 1.07 (s, 9H, tBu). ${ }^{13} \mathrm{C}$ NMR (125 MHz, $\left.\mathrm{CDCl}_{3}\right): \delta 170.3(\mathrm{Cq}), 162.9(\mathrm{Cq}), 131.9(\mathrm{Cq}), 129.3$ ( $\mathrm{CH}$ Ar), $114.1\left(\mathrm{CH}\right.$ Ar), $73.6(\mathrm{Cq}), 63.0\left(\mathrm{CHCH}_{2} \mathrm{OtBu}\right), 56.3\left(\mathrm{CHCH}_{2} \mathrm{OtBu}\right), 55.6\left(\mathrm{PhOCH}_{3}\right), 52.4$ $\left(\mathrm{COOCH}_{3}\right), 27.2(\mathrm{tBu})$.

\section{Synthesis of compound 5}

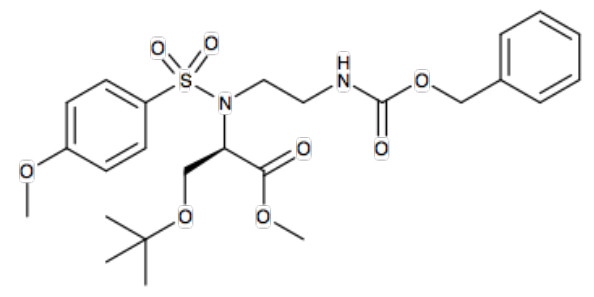

To a stirred solution of 4 (860 mg, $2.49 \mathrm{mmol})$, N-Z-ethanolamine $(584 \mathrm{mg}, 2.99 \mathrm{mmol})$ and $\mathrm{PPh}_{3}(784 \mathrm{mg}$, $2.99 \mathrm{mmol})$ in dry THF $(45.0 \mathrm{~mL})$, DIAD $(2.99 \mathrm{mmol}, 0.589 \mathrm{~mL})$ was slowly added. The mixture was stirred overnight at $\mathrm{rt}$ then concentrated to dryness. $15 \mathrm{~mL}$ of a mixture EtOAc:Petroleum Ether 1:8 were added and the suspension was stirred for 30' at room temperature. The white solid was filtered off and the filtrate was concentrated to dryness. The crude product was purified by flash column chromatography on silica gel $\left(\mathrm{CH}_{2} \mathrm{Cl}_{2}\right.$ :acetone $\left.40: 1\right)$ to give $5(2.05 \mathrm{mmol}, 82 \%)$ as a yellow oil. $[\alpha]_{\mathrm{D}}{ }^{25}+22.5$ (c 0.6, $\left.\mathrm{CHCl}_{3}\right)$; ESI-MS $1067.03[2 \mathrm{M}+\mathrm{Na}]^{+} ;{ }^{1} \mathrm{H} \mathrm{NMR}\left(500 \mathrm{MHz}, \mathrm{CDCl}_{3}\right): \delta 7.77\left(\mathrm{AA}^{\prime}\right.$ part of an AA'MM' system, $J_{A M}=8.8 \mathrm{~Hz}$, 2H), 7.37-7.30 (m, 5H, Bn), 6.94 (MM' part of an AA'MM' system, $\left.J_{M A}=8.8 \mathrm{~Hz}, 2 \mathrm{H}\right), 5.81$ (bs, NH), 5.12 (A part of a $\mathrm{AB}$ system, $J_{A B}=12.3 \mathrm{~Hz}, 1 \mathrm{H}, \mathrm{CH}_{2} \mathrm{Ph}$ ), 5.07 (B part of a $\mathrm{AB}$ system, $J_{B A}=12.3 \mathrm{~Hz}, 1 \mathrm{H}, \mathrm{CH}_{2} \mathrm{Ph}$ ), $4.67\left(\mathrm{X}\right.$ part of a ABX system, $J x_{A}=3.8 \mathrm{~Hz}, J x_{B}=3.8 \mathrm{~Hz}, 1 \mathrm{H}, \mathrm{CHCH}_{2} \mathrm{OtBu}$ ), $3.85\left(\mathrm{~s}, 3 \mathrm{H}, \mathrm{PhOCH}_{3}\right), 3.83-$ $3.74\left(\mathrm{~m}, 2 \mathrm{H}, \mathrm{NCH}_{2} \mathrm{CH}_{2} \mathrm{NH}\right), 3.64$ (s, $\left.3 \mathrm{H}, \mathrm{COOCH}_{3}\right), 3.52-3.39\left(\mathrm{~m}, 2 \mathrm{H}, \mathrm{NCH}_{2} \mathrm{CH}_{2} \mathrm{NH}\right), 1.13(\mathrm{~s}, 3 \mathrm{H}, \mathrm{tBu}) .{ }^{13} \mathrm{C}$ NMR (125 MHz, $\left.\mathrm{CDCl}_{3}\right): \delta 170.1(\mathrm{Cq}), 162.9(\mathrm{Cq}), 156.5(\mathrm{Cq}), 136.8(\mathrm{Cq}), 131.4(\mathrm{Cq}), 129.6(\mathrm{CH} \mathrm{Ar})$, $128.4\left(\mathrm{CH}\right.$ Ar, Bn), 128.0 ( $\mathrm{CH}$ Ar, Bn), 127.9 (CH Ar, Bn), $114.0(\mathrm{CH} \mathrm{Ar}), 66.5\left(\mathrm{CH}_{2} \mathrm{Ph}\right), 60.8$ 
$\left(\mathrm{CHCH}_{2} \mathrm{OtBu}\right), 60.7 \quad\left(\underline{\mathrm{C}} \mathrm{HCH}_{2} \mathrm{OtBu}\right), 55.6 \quad\left(\mathrm{PhOCH}_{3}\right), 52.3 \quad\left(\mathrm{COOCH}_{3}\right), 46.2 \quad\left(\mathrm{NCH}_{2} \mathrm{CH}_{2} \mathrm{NH}\right), 40.8$ $\left(\mathrm{NCH}_{2} \mathrm{CH}_{2} \mathrm{NH}\right), 27.2(\mathrm{tBu})$.

\section{Synthesis of compound 6 VBA_12014}

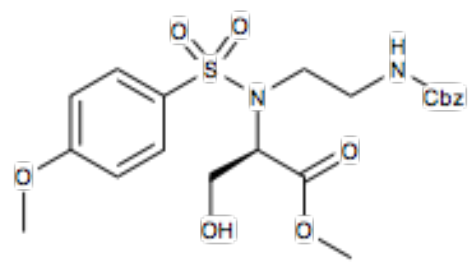

To a stirred solution of $5(530 \mathrm{mg}, 1.01 \mathrm{mmol})$ in $\mathrm{CH}_{2} \mathrm{Cl}_{2}(15.0 \mathrm{~mL})$, TFA $(40.4 \mathrm{mmol}, 3.1 \mathrm{~mL})$ was added and the mixture was stirred at $\mathrm{rt}$ for $2 \mathrm{~h}$. After this time the solvent was evaporated under reduced pressure to obtain a crude which was purified by flash column chromatography on silica gel $\left(\mathrm{CH}_{2} \mathrm{Cl}_{2}\right.$ :acetone $\left.12: 1\right)$ to give $6(0.86 \mathrm{mmol}, 85 \%)$ as a colorless oil. $[\alpha]_{\mathrm{D}}^{25}+31.27\left(\mathrm{c} 0.55, \mathrm{CHCl}_{3}\right)$; ESI-MS $489.50[\mathrm{M}+\mathrm{Na}]^{+}, 955.07$ $[2 \mathrm{M}+\mathrm{Na}]^{+} ;{ }^{1} \mathrm{H}$ NMR $\left(500 \mathrm{MHz}, \mathrm{CDCl}_{3}\right): \delta 7.74\left(\mathrm{AA}^{\prime}\right.$ part of an AA'MM' system, $\left.J_{A M}=8.8 \mathrm{~Hz}, 2 \mathrm{H}\right), 7.37-$ $7.31(\mathrm{~m}, 5 \mathrm{H}, \mathrm{Bn}), 6.96$ (MM' part of an AA'MM' system, $\left.J_{M A}=8.8 \mathrm{~Hz}, 2 \mathrm{H}\right), 5.52(\mathrm{bs}, \mathrm{NH}), 5.12$ (A part of a $\mathrm{AB}$ system, $\left.J_{A B}=12.2 \mathrm{~Hz}, 1 \mathrm{H}, \mathrm{CH}_{2} \mathrm{Ph}\right), 5.09\left(\mathrm{~B}\right.$ part of a $\mathrm{AB}$ system, $\left.J_{B A}=12.3 \mathrm{~Hz}, 1 \mathrm{H}, \mathrm{CH}_{2} \mathrm{Ph}\right), 4.60(\mathrm{X}$ part of an ABX system, $\left.J_{X A}=4.1 \mathrm{~Hz}, J_{X B}=4.2 \mathrm{~Hz}, 1 \mathrm{H}, \mathrm{C}^{\mathrm{HCH}} \mathrm{H}_{2} \mathrm{OH}\right), 4.07-3.98\left(\mathrm{~m}, 2 \mathrm{H}, \mathrm{CHC}_{2} \mathrm{OH}\right), 3.86(\mathrm{~s}$, $\left.3 \mathrm{H}, \mathrm{PhOCH}_{3}\right), 3.55\left(\mathrm{~s}, 3 \mathrm{H}, \mathrm{COOCH}_{3}\right), 3.53-3.47\left(\mathrm{~m}, 2 \mathrm{H}, \mathrm{NCH}_{2} \mathrm{CH}_{2} \mathrm{NH}\right), 3.44-3.38\left(\mathrm{~m}, 2 \mathrm{H}, \mathrm{NCH}_{2} \mathrm{CH}_{2} \mathrm{NH}\right)$. ${ }^{13} \mathrm{C}$ NMR (125 MHz, $\left.\mathrm{CDCl}_{3}\right): \delta 169.7(\mathrm{Cq}), 163.1(\mathrm{Cq}), 157.1(\mathrm{Cq}), 136.3(\mathrm{Cq}), 130.6(\mathrm{Cq}), 129.6(\mathrm{CH} \mathrm{Ar})$, 128.5 ( $\mathrm{CH} \mathrm{Ar}), 128.1(\mathrm{CH} \mathrm{Ar}), 128.1(\mathrm{CH} \mathrm{Ar}), 114.1(\mathrm{CH} \mathrm{Ar}), 67.0\left(\mathrm{CH}_{2} \mathrm{Ph}\right), 62.0\left(\mathrm{CHCH}_{2} \mathrm{OH}\right), 55.6$ $\left(\mathrm{PhOCH}_{3}\right), 52.3\left(\mathrm{COOCH}_{3}\right), 45.2\left(\mathrm{NCH}_{2} \mathrm{CH}_{2} \mathrm{NH}\right), 41.5\left(\mathrm{NCH}_{2} \mathrm{CH}_{2} \mathrm{NH}\right)$.

\section{Synthesis of compound 7 VBA_13014}

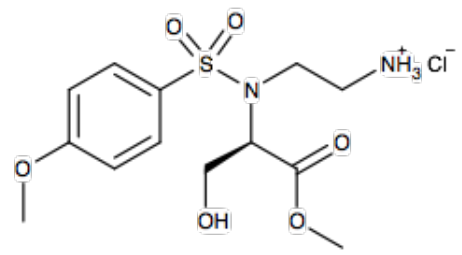

$\mathrm{Pd}(\mathrm{OH})_{2} / \mathrm{C}(20 \% \mathrm{Pd}$ content, $225 \mathrm{mg})$ was added to a stirred solution of $6(500 \mathrm{mg}, 1.07 \mathrm{mmol})$ and $\mathrm{HCl}$ $12 \mathrm{M}(0.178 \mathrm{~mL})$ in a mixture EtOAc:MeOH 3:1 $(12.0 \mathrm{~mL})$. The mixture was stirred at $\mathrm{rt}$ for $2 \mathrm{~h}$ under a $\mathrm{H}_{2}$ atmosphere then filtered through a pad of Celite. The filtrate was concentrated to dryness to give 7 (1.02 mmol, 95\%) as a glassy solid. $[\alpha]_{\mathrm{D}}{ }^{25}+25.0\left(\mathrm{c} 0.5, \mathrm{CH}_{3} \mathrm{OH}\right)$; ESI-MS $333.01[\mathrm{M}+\mathrm{H}]^{+} ;{ }^{1} \mathrm{H}$ NMR (500 MHz, $\mathrm{CD}_{3} \mathrm{OD}$ ): $\delta 7.80$ (AA' part of an AA'MM' system, $J_{A M}=7.4 \mathrm{~Hz}, 2 \mathrm{H}$ ), 7.11 (MM' part of an AA'MM' system, $\left.J_{M A}=7.3 \mathrm{~Hz}, 2 \mathrm{H}\right), 4.77-4.72\left(\mathrm{~m}, 1 \mathrm{H}, \mathrm{CHCH}_{2} \mathrm{OH}\right), 4.03-3.96\left(\mathrm{~m}, 1 \mathrm{H}, \mathrm{CHC}_{2} \mathrm{OH}\right), 3.90(\mathrm{~s}, 3 \mathrm{H}$, $\left.\mathrm{PhOCH}_{3}\right), 3.88-3.86\left(\mathrm{~m}, 1 \mathrm{H}, \mathrm{CHCH}_{2} \mathrm{OH}\right), 3.70-3.63\left(\mathrm{~m}, 2 \mathrm{H}, \mathrm{NCH}_{2} \mathrm{CH}_{2} \mathrm{NH}\right), 3.61\left(\mathrm{~s}, 3 \mathrm{H}, \mathrm{COOCH}_{3}\right), 3.34-$ $3.21\left(\mathrm{~m}, 2 \mathrm{H}, \mathrm{NCH}_{2} \mathrm{CH}_{2} \mathrm{NH}\right) ;{ }^{13} \mathrm{C}$ NMR (125 MHz, CD $\left.3 \mathrm{OD}\right): \delta 170.4(\mathrm{Cq}), 163.7(\mathrm{Cq}), 130.0 .5(\mathrm{Cq}), 129.5$ ( $\mathrm{CH} \mathrm{Ar}), 114.2\left(\mathrm{CH}\right.$ Ar), $61.9\left(\underline{\mathrm{CHCH}}{ }_{2} \mathrm{OH}\right), 60.4\left(\mathrm{CH}_{\underline{C}} \mathrm{H}_{2} \mathrm{OH}\right), 55.2\left(\mathrm{PhOCH}_{3}\right), 51.9\left(\mathrm{COOCH}_{3}\right), 43.4$ $\left(\mathrm{NCH}_{2} \mathrm{CH}_{2} \mathrm{NH}\right), 39.7\left(\mathrm{NCH}_{2} \mathrm{CH}_{2} \mathrm{NH}\right)$ 


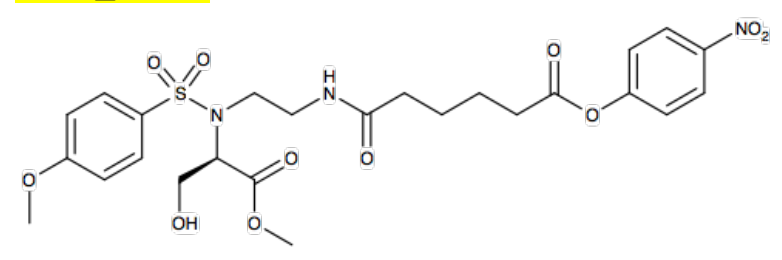

To a stirred solution of the para nitro phenyl ester of the butyric acid (1.54 g, $3.96 \mathrm{mmol})$ and NMM $(0.272$ $\mathrm{mL}, 2.44 \mathrm{mmol})$ in dry DMF $(4.0 \mathrm{~mL})$, a solution of $7(364 \mathrm{mg}, 0.99 \mathrm{mmol})$ in dry DMF $(10.0 \mathrm{~mL})$ was added. The mixture was stirred at $\mathrm{rt}$ for $4 \mathrm{~h}$ then concentrated to dryness. The crude product was purified by column flash chromatography on silica gel (EtOAc:Petroleum Ether 10:1) to give $8(0.73 \mathrm{mmol}, 74 \%)$ as a colorless oil. $[\alpha]_{\mathrm{D}}{ }^{25}+30.92\left(\mathrm{c} 0.65, \mathrm{CHCl}_{3}\right)$; ESI-MS $604.11[\mathrm{M}+\mathrm{Na}]^{+} ;{ }^{1} \mathrm{H} \mathrm{NMR}\left(500 \mathrm{MHz}, \mathrm{CDCl}_{3}\right): \delta 8.26$ (AA' part of an AA'MM' system, $J_{A M}=9.0 \mathrm{~Hz}, 2 \mathrm{H}$ ), 7.72 (A part of an AA'MM' system, $J_{A M}=8.8 \mathrm{~Hz}, 2 \mathrm{H}$ ), 7.30 (MM' part of an AA'MM' system, $J_{M A}=8.9 \mathrm{~Hz}, 2 \mathrm{H}$ ), 6.97 (MM' part of an AA'MM' system, $J_{M A}=8.8$ $\mathrm{Hz}, 2 \mathrm{H}$ ), 6.58-6.48 (bs, NH), 4.61 (X part of an ABX system, $J_{X A}=3.9 \mathrm{~Hz}, J_{X B}=3.9 \mathrm{~Hz}, 1 \mathrm{H}, \mathrm{CHCH}_{2} \mathrm{OH}$ ), 4.08-4.00 (m, $\left.2 \mathrm{H}, \mathrm{CH}_{2} \mathrm{OH}\right), 3.88\left(\mathrm{~s}, 3 \mathrm{H}, \mathrm{PhOCH}_{3}\right), 3.70-3.65\left(\mathrm{~m}, 1 \mathrm{H}, \mathrm{NC}_{2} \mathrm{CH}_{2} \mathrm{NH}\right), 3.58-3.53(\mathrm{~m}, 1 \mathrm{H}$, $\left.\mathrm{NCH}_{2} \underline{\mathrm{C}}_{2} \mathrm{NH}\right), 3.54$ (s, 3H, $\left.\mathrm{COOCH}_{3}\right), 3.48-3.43\left(\mathrm{~m}, 1 \mathrm{H}, \mathrm{NCH}_{2} \underline{\mathrm{C}}_{2} \mathrm{NH}\right), 3.41-3.40\left(\mathrm{~m}, 1 \mathrm{H}, \mathrm{NC}_{2} \mathrm{CH}_{2} \mathrm{NH}\right)$, 2.65 (at, $2 \mathrm{H}, \mathrm{CH}_{2} \mathrm{COOPhNO}_{2}$ ), 2.31 (at, $\left.2 \mathrm{H}, \mathrm{NHCOCH}_{2}\right), 1.82-1.80$ (m, 4H, $-\mathrm{CH}_{2} \mathrm{CH}_{2}$ ); ${ }^{13} \mathrm{C}$ NMR $(125$ $\left.\mathrm{MHz}, \mathrm{CDCl}_{3}\right): \delta 173.7(\mathrm{Cq}), 171.0(\mathrm{Cq}), 169.6(\mathrm{Cq}), 163.2(\mathrm{Cq}), 155.5(\mathrm{Cq}), 145.3(\mathrm{Cq}), 130.6(\mathrm{Cq}), 129.5$

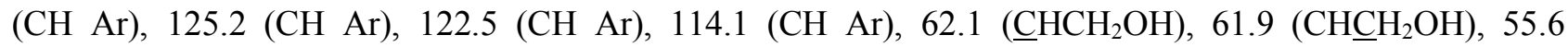
$\left(\mathrm{PhOCH}_{3}\right), \quad 52.3 \quad\left(\mathrm{COOCH}_{3}\right), 45.7 \quad\left(\mathrm{NCH}_{2} \underline{\mathrm{CH}}_{2} \mathrm{NH}\right), 39.8 \quad\left(\mathrm{NCH}_{2} \mathrm{CH}_{2} \mathrm{NH}\right), 35.9 \quad\left(\mathrm{NHCOCH}_{2}\right), 34.0$ $\left(\mathrm{CH}_{2} \mathrm{COOPhNO}_{2}\right), 24.6\left(-\mathrm{CH}_{2} \mathrm{CH}_{2}-\right), 24.2\left(-\mathrm{CH}_{2} \mathrm{CH}_{2}-\right)$.

\section{Synthesis of compound 9 VBA_13314}

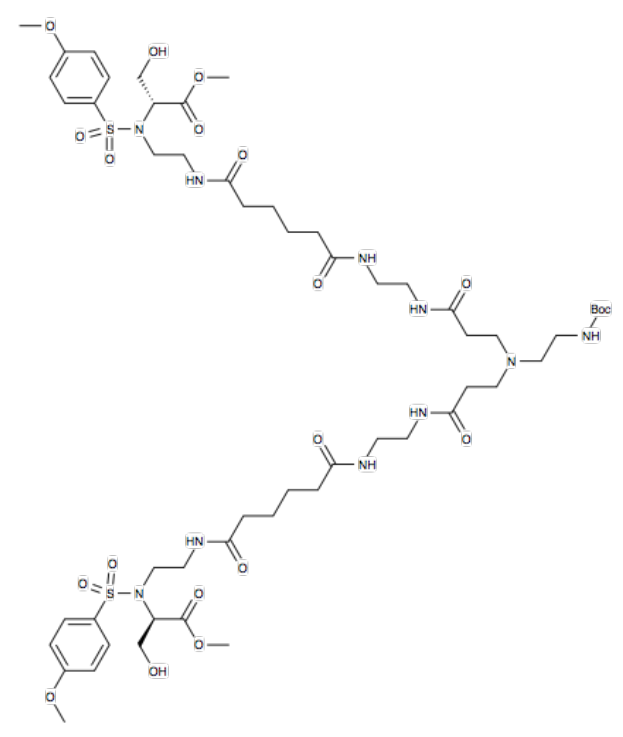

To a stirred solution of $\mathbf{8}(1.0 \mathrm{mmol}, 581 \mathrm{mg})$ in dry DMF $(5.0 \mathrm{~mL})$, a solution of $\mathbf{2}(0.5 \mathrm{mmol}, 194 \mathrm{mg})$ and NMM $(2.0 \mathrm{mmol}, 0.220 \mathrm{~mL})$ in dry DMF $(5 \mathrm{~mL})$ was added. The mixture was stirred at $\mathrm{rt}$ for $2 \mathrm{~h}$ then concentrated to dryness. The crude product was purified by column flash chromatography on silica gel $\left(\mathrm{CH}_{2} \mathrm{Cl}_{2}: \mathrm{MeOH} 8: 1\right.$ to $\left.4: 1\right)$ to give $9(0.72 \mathrm{mmol}, 72 \%)$. [ $\left.\alpha\right]_{\mathrm{D}}{ }^{25}+26.8$ (c $\left.0.75, \mathrm{CHCl}_{3}\right)$; ESI-MS 648.23 
$[\mathrm{M}+\mathrm{H}+\mathrm{Na}]^{+}, 659.33[\mathrm{M}+2 \mathrm{Na}]^{+}, 1273.15[\mathrm{M}+\mathrm{H}]^{+}, 1295.17[\mathrm{M}+\mathrm{Na}]^{+} ;{ }^{1} \mathrm{H} \mathrm{NMR}\left(500 \mathrm{MHz}, \mathrm{CD}_{3} \mathrm{OD}\right): \delta 7.78$ (AA' part of an AA'MM' system, $J_{A M}=9.0 \mathrm{~Hz}, 4 \mathrm{H}$ ), 7.08 (MM' part of an AA'MM' system, $J_{M A}=9 \mathrm{~Hz}$, $4 \mathrm{H}$ ), 4.62 (X part of an ABX system, $\left.J_{X A}=5.1 \mathrm{~Hz}, J_{X B}=5.1 \mathrm{~Hz}, 2 \mathrm{H}, \mathrm{CHCH}_{2} \mathrm{OH}\right), 3.97-3.93(\mathrm{~m}, 4 \mathrm{H}$, $\left.\mathrm{CH}_{2} \mathrm{OH}\right), 3.89\left(\mathrm{~s}, 6 \mathrm{H}, \mathrm{PhOCH}_{3}\right), 3.55\left(\mathrm{~s}, 6 \mathrm{H}, \mathrm{COOCH}_{3}\right), 3.53-3.36\left(\mathrm{~m}, 2 \times 2 \mathrm{H}, \mathrm{NCH}_{2} \mathrm{CH}_{2} \mathrm{NH}\right), 3.43-3.36(\mathrm{~m}$, $\left.2 \times 2 \mathrm{H}, \mathrm{NCH}_{2} \mathrm{CH}_{2} \mathrm{NH}\right), 3.31\left(\mathrm{~s}, 8 \mathrm{H}, \mathrm{HNCH}_{2} \mathrm{CH}_{2} \mathrm{NH}\right), 3.15$ (t, $J=6.5 \mathrm{~Hz}, 2 \mathrm{H}, \mathrm{NCH}_{2} \mathrm{C}_{2} \mathrm{NHBoc}_{\text {), }} .78$ (t, $J=$ $6.7 \mathrm{~Hz}, 4 \mathrm{H}, \mathrm{HNCOCH}_{2} \underline{\mathrm{H}}_{2} \mathrm{~N}$ ), 2.57 (t, $\left.J=6.4 \mathrm{~Hz}, 2 \mathrm{H}, \mathrm{NC}_{2} \mathrm{CH}_{2} \mathrm{NHBoc}\right), 2.37$ (t, $J=6.6 \mathrm{~Hz}, 4 \mathrm{H}$, $\mathrm{HNCOC} \underline{H}_{2} \mathrm{CH}_{2} \mathrm{~N}$ ), 2.24-2.20 (m, 8H, OCC $\underline{\mathrm{H}}_{2} \mathrm{CH}_{2} \mathrm{CH}_{2} \underline{\mathrm{C}}_{2} \mathrm{CO}$ ), 1.65-1.62 (m, 8H, OCCH $\mathrm{C}_{2} \mathrm{C}_{2} \mathrm{CH}_{2} \mathrm{CO}$ ), $1.44(\mathrm{~s}, 9 \mathrm{H}, \mathrm{tBu}) ;{ }^{13} \mathrm{C}$ NMR (125 MHz, $\left.\mathrm{CD}_{3} \mathrm{OD}\right): \delta 174.7(\mathrm{Cq}), 174.6(\mathrm{Cq}), 173.9(\mathrm{Cq}), 170.0(\mathrm{Cq}), 163.4$ $(\mathrm{Cq}), 156.9(\mathrm{Cq}), 130.9(\mathrm{Cq}), 129.4(\mathrm{CH} \mathrm{Ar}), 113.9(\mathrm{CH} \mathrm{Ar}), 62.0\left(\underline{\mathrm{CHCH}}_{2} \mathrm{OH}\right), 60.6\left(\mathrm{CHCH}_{2} \mathrm{OH}\right), 54.9$ $\left(\mathrm{PhOCH}_{3}\right), 52.08\left(\mathrm{NCH}_{2} \mathrm{CH}_{2} \mathrm{NHBoc}\right), 51.3\left(\mathrm{COOCH}_{3}\right), 49.5\left(\mathrm{HNCOCH}_{2} \mathrm{CH}_{2} \mathrm{~N}\right), 44.9\left(\mathrm{NCH}_{2} \mathrm{CH}_{2} \mathrm{NH}\right), 39.5$ $\left(\mathrm{NC}_{2} \mathrm{CH}_{2} \mathrm{NH}\right), 38.7\left(\mathrm{HNCH}_{2} \mathrm{CH}_{2} \mathrm{NH}\right), 37.8\left(\mathrm{NCH}_{2} \underline{\mathrm{CH}_{2}} \mathrm{NHBoc}\right), 35.4-35.3\left(\mathrm{OC}^{-} \mathrm{H}_{2} \mathrm{CH}_{2} \mathrm{CH}_{2} \underline{\mathrm{C}} \mathrm{H}_{2} \mathrm{CO}\right), 33.1$ $\left(\mathrm{HNCO} \underline{\mathrm{C}} \mathrm{H}_{2} \mathrm{CH}_{2} \mathrm{~N}\right), 27.4(\mathrm{tBu}), 25.1-24.9\left(\mathrm{OCCH}_{2} \underline{\mathrm{CH}_{2}} \underline{\mathrm{CH}}_{2} \mathrm{CH}_{2} \mathrm{CO}\right)$.

\section{Synthesis of compound 3 VBA_13714}

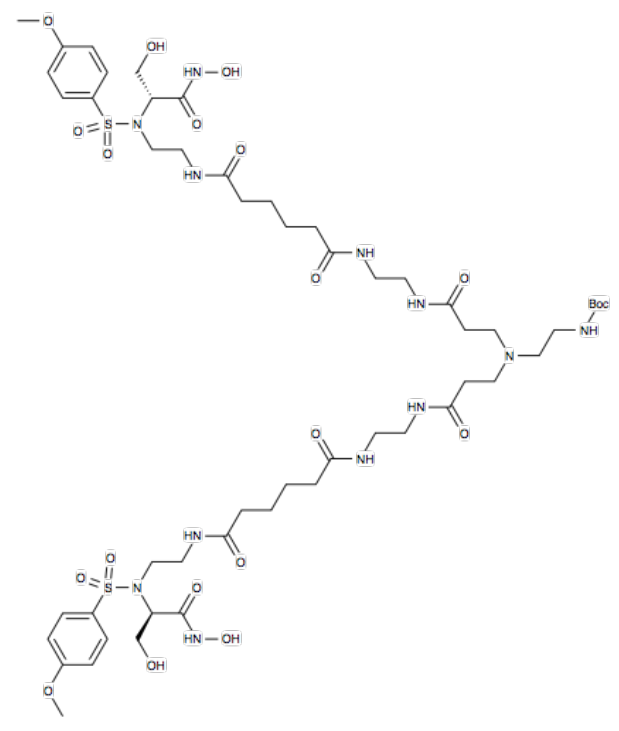

A suspension of $\mathrm{KOH}(630 \mathrm{mg}, 11.2 \mathrm{mmol})$ in $\mathrm{MeOH}(2.3 \mathrm{~mL})$ and a suspension of $\mathrm{NH}_{2} \mathrm{OH} \cdot \mathrm{HCl}(670 \mathrm{mg}$, $9.64 \mathrm{mmol})$ in $\mathrm{MeOH}(4.5 \mathrm{~mL})$ were separately stirred for $10^{\prime}$ at $70^{\circ} \mathrm{C}$. Then the solution of $\mathrm{KOH}$ was added to the solution of $\mathrm{NH}_{2} \mathrm{OH} \cdot \mathrm{HCl}$ and the mixture was stirred at $60^{\circ} \mathrm{C}$ for $10^{\prime}$. Then $9(50 \mathrm{mg}, 0.04 \mathrm{mmol})$ was dissolved in $0.680 \mathrm{~mL}$ of the freshly obtained suspension of $\mathrm{NH}_{2} \mathrm{OH}$. The mixture was stirred at $\mathrm{rt}$ for $3 \mathrm{~h}$ then diluted with $\mathrm{MeOH}(5 \mathrm{~mL})$ and the solid was filtered off. The filtrate was concentrated to dryness to give $65 \mathrm{mg}$ of crude product, which was purified by HPLC (column Zorbax 300SB-C18, 9.4x250, 5 um, $\left.\mathrm{H}_{2} \mathrm{O}: \mathrm{MeOH} 50: 50\right)$ to give $3(0.012 \mathrm{mmol}, 30 \%)$ as a glassy solid. ESI-MS $649.31[\mathrm{M}+\mathrm{H}+\mathrm{Na}]^{+}, 660.53$ $[\mathrm{M}+2 \mathrm{Na}]^{+}, 1275.33[\mathrm{M}+\mathrm{H}]^{+}, 1297.40[\mathrm{M}+\mathrm{Na}]^{+} ;{ }^{1} \mathrm{H} \mathrm{NMR}\left(500 \mathrm{MHz}, \mathrm{CD}_{3} \mathrm{OD}\right.$ ): $\delta 7.81$ (AA' part of an AA'MM' system, $J_{A M}=8.8 \mathrm{~Hz}, 4 \mathrm{H}$ ), 7.06 (MM' part of an AA'MM' system, $J_{M A}=8.8 \mathrm{~Hz}, 4 \mathrm{H}$ ), 4.37 (at, $\left.2 \mathrm{H}, \mathrm{CHCH}_{2} \mathrm{OH}\right), 3.89\left(\mathrm{~s}, 6 \mathrm{H}, \mathrm{PhOCH}_{3}\right), 3.86-3.82\left(\mathrm{~m}, 1 \times 2 \mathrm{H}, \mathrm{CHC}_{2} \mathrm{OH}\right), 3.76-3.72\left(\mathrm{~m}, 1 \mathrm{x} 2 \mathrm{H}, \mathrm{CHC}_{2} \mathrm{OH}\right)$, 3.69-3.63 (m, $\left.1 \times 2 \mathrm{H}, \quad \mathrm{NC}_{2} \mathrm{CH}_{2} \mathrm{NH}\right), 3.60-3.39\left(\mathrm{~m}, 2 \times 2 \mathrm{H}, \mathrm{NCH}_{2} \underline{\mathrm{C}}_{2} \mathrm{NH}\right), \quad 3.41-3.35(\mathrm{~m}, 1 \times 2 \mathrm{H}$, $\mathrm{NC}_{2} \mathrm{CH}_{2} \mathrm{NH}$ ), 3.31 (s, 8H, $\mathrm{HNCH}_{2} \mathrm{CH}_{2} \mathrm{NH}$ ), 3.14 (t, $J=6.4 \mathrm{~Hz}, 2 \mathrm{H}, \mathrm{NCH}_{2} \mathrm{CH}_{2} \mathrm{NHBoc}, 2.77$ (t, $J=6.2 \mathrm{~Hz}$, $\left.4 \mathrm{H}, \mathrm{HNCOCH}_{2} \underline{\mathrm{C}}_{2} \mathrm{~N}\right), 2.55\left(\mathrm{t}, J=6.2 \mathrm{~Hz}, 2 \mathrm{H}, \mathrm{NC}_{2} \mathrm{CH}_{2} \mathrm{NHBoc}\right), 2.36(\mathrm{t}, J=6.3 \mathrm{~Hz}, 4 \mathrm{H}$, $\mathrm{HNCOCH}_{2} \mathrm{CH}_{2} \mathrm{~N}$ ), 2.27-2.19 (m, 8H, OCC $\underline{\mathrm{H}}_{2} \mathrm{CH}_{2} \mathrm{CH}_{2} \underline{\mathrm{CH}}_{2} \mathrm{CO}$ ), 1.68-1.60 (m, 8H, OCCH${ }_{2} \underline{\mathrm{C}}_{2} \mathrm{C}_{2} \mathrm{CH}_{2} \mathrm{CO}$ ), 1.44 (s, 9H, tBu); ${ }^{13} \mathrm{C}$ NMR (125 MHz, CD $\left.3 \mathrm{OD}\right): \delta 174.8(\mathrm{Cq}), 174.6(\mathrm{Cq}), 173.9(\mathrm{Cq}), 166.9(\mathrm{Cq}), 163.3$ 
$(\mathrm{Cq}), 156.9(\mathrm{Cq}), 130.9(\mathrm{Cq}), 129.3\left(\mathrm{CH}\right.$ Ar), $113.9\left(\mathrm{CH}\right.$ Ar), $60.0\left(\mathrm{CH}_{\underline{C}} \mathrm{H}_{2} \mathrm{OH}\right), 59.4\left(\underline{\mathrm{CHCH}}{ }_{2} \mathrm{OH}\right), 54.8$ $\left(\mathrm{PhOCH}_{3}\right), 52.1\left(\mathrm{NCH}_{2} \mathrm{CH}_{2} \mathrm{NHBoc}\right), 49.5\left(\mathrm{HNCOCH}_{2} \mathrm{CH}_{2} \mathrm{~N}\right), 43.9\left(\mathrm{NCH}_{2} \mathrm{CH}_{2} \mathrm{NH}\right), 39.6\left(\mathrm{NCH}_{2} \mathrm{CH}_{2} \mathrm{NH}\right)$, $38.7 \quad\left(\mathrm{HNCH}_{2} \mathrm{CH}_{2} \mathrm{NH}\right), \quad 37.9 \quad\left(\mathrm{NCH}_{2} \underline{\mathrm{CH}}_{2} \mathrm{NHBoc}\right), \quad 35.4-35.3 \quad\left(\mathrm{OCCCH}_{2} \mathrm{CH}_{2} \mathrm{CH}_{2} \underline{\mathrm{CH}}_{2} \mathrm{CO}\right), \quad 33.1$ ( $\left.\mathrm{HNCO} \underline{\mathrm{CH}} \mathrm{C}_{2} \mathrm{CH}_{2} \mathrm{~N}\right), 27.4(\mathrm{tBu}), 25.0-24.9\left(\mathrm{OCCH}_{2} \underline{\mathrm{CH}}_{2} \underline{\mathrm{CH}}_{2} \mathrm{CH}_{2} \mathrm{CO}\right)$.

\section{In vivo test}

Formulation. A $157 \mu \mathrm{M}$ solution of compound $3(1 \mathrm{mg} / 5 \mathrm{ml}$, in $\mathrm{NaCl} 0.9 \%$ physiological solution) was used for in vivo test. The formulation was sterilized by filtration $(0.22 \mu \mathrm{m}$, Minisart, Sartorius SpA, Florence, Italy) and did not contain preservatives since it was used immediately after opening the vials.

\section{SAXS Experiments}

Small Angle X-ray Scattering (SAXS) experiments were carried out at the SAXS beamline of Elettra Synchrotron (Basovizza, Trieste, Italy) with the following experimental parameters: $\mathrm{E}=8$ $\mathrm{keV}, \lambda=1.54 \AA$, sample-to-detector distance $=1.3 \mathrm{~m}$, available Q-range $=0.0067-0.46 \AA^{-1}$. The samples were enclosed in a quartz capillary of $1 \mathrm{~mm}$ exact thickness, and the measurements were performed at room temperature and ambient pressure. Data collected by the 2D detector were circularly integrated using the freeware program FIT2D. Standard correction procedures were applied for sample volume, detector efficiency and background signal subtraction. Ten acquisitions (of 20 seconds each) were averaged for each sample. Data treatment and analysis were performed using Wavemetrics's software "Igor Pro" and the macros provided by the NIST. ${ }^{\text {S1 }}$

The samples MMP_3 and MMP_NNGH, both at the concentration of $8 \mathrm{mg} / \mathrm{mL}$, were analysed by means of small-angle X-ray scattering (SAXS). Fig. S1 presents the SAXS spectra obtained for the two samples, after subtraction of the background (the buffer), where the scattered intensity I(Q) is plotted as a function of the scattering vector $\mathrm{Q}$, defined as $4 \pi \sin (\theta) / \lambda$, with $2 \theta$ the scattering angle. A first inspection of the spectra reveals a different structure at the nanoscale for the two samples.

Figure S1. SAXS spectra for the samples MMP_3 and MMP_NNGH, both at the concentration of $8 \mathrm{mg} / \mathrm{mL}$.

The scattered intensity $I(Q)$ can be written as:

$$
I(Q)=N V^{2} \Delta \rho^{2} P(Q) S(Q)
$$

Eq. A

with $\mathrm{N}$ the number density of the scattering objects, $\mathrm{V}$ their volume, $\Delta \rho^{2}$ the contrast (difference of electron density) between scatterer and solvent. $\mathrm{P}(\mathrm{Q})$ is the intraparticle structure factor, also called Form Factor, and $\mathrm{S}(\mathrm{Q})$ the interparticle structure factor, which is assumed equal to 1 for dilute non interacting samples.

The spectra were interpreted assuming a pure form factor contribution $\mathrm{P}(\mathrm{Q})$. The fitting procedure was performed using the NIST macros for Wavemetrics Igor Pro. ${ }^{\mathrm{S} 1}$ The fixed parameters were the scattering length densities (SLDs) of the protein $\left(1.2310^{-6} \AA^{-2}\right)^{\mathrm{S} 2}$ and the solvent $\left(9.3610^{-6} \AA^{-2}\right)$, as well as the background level, while the other parameters were inferred from a fitting of the experimental data.

The curve for sample MMP_NNGH was easily modelled as a form factor of ellipsoids (Fig. S2), yielding $14.82 \pm 0.09 \AA$ for the two identical semi-minor axes, and $21.70 \pm 0.05 \AA$ for the semimajor axis (oblate ellipsoid of revolution). The spectrum of MMP_3 was more adequately fitted by 
a form factor of cylinders with polydisperse length (Fig. S3), yielding $15.38 \pm 0.04 \AA$ for the radius and an average length $56.8 \pm 0.5 \AA$ (35\% polydispersity). The results for MMP_3 are in agreement with an object of similar shape but twice the size as in sample MMP_NNGH.

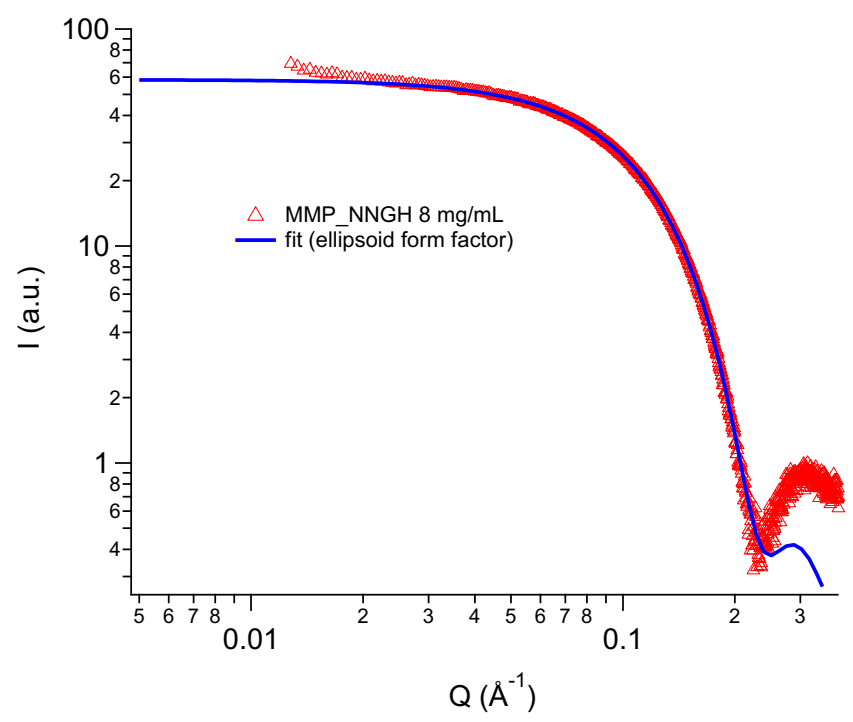

Fig. S2. Fitting of the SAXS spectrum of MMP_NNGH with a form factor of ellipsoids

Fig. S3. Fitting of the SAXS spectrum of MMP_3 with a form factor of cylinders

In both cases we were able to adequately fit the experimental data and estimate a radius of gyration for the two samples thanks to a Guinier linearization in the low-Q region, according to: ${ }^{\mathrm{S}}$

$$
\operatorname{Ln}[I(Q)]=\operatorname{Ln}\left[I_{0}\right]-\frac{Q^{2} R_{g}^{2}}{3} \quad \text { Eq. B }
$$

By plotting $\operatorname{Ln}[\mathrm{I}(\mathrm{Q})]$ vs. $\mathrm{Q}^{2}$, it was possible to extract $\mathrm{R}_{\mathrm{g}}$ from the slope $\mathrm{R}_{\mathrm{g}}{ }^{2} / 3$ (Figs. S4 and S5). The radii of gyration thereby obtained were $15.2 \pm 1.7 \AA$ for MMP_NNGH and $23.8 \pm 1.2 \AA$ for MMP_3. In both cases, the condition $\mathrm{QR}_{\mathrm{g}}<1$ was respected

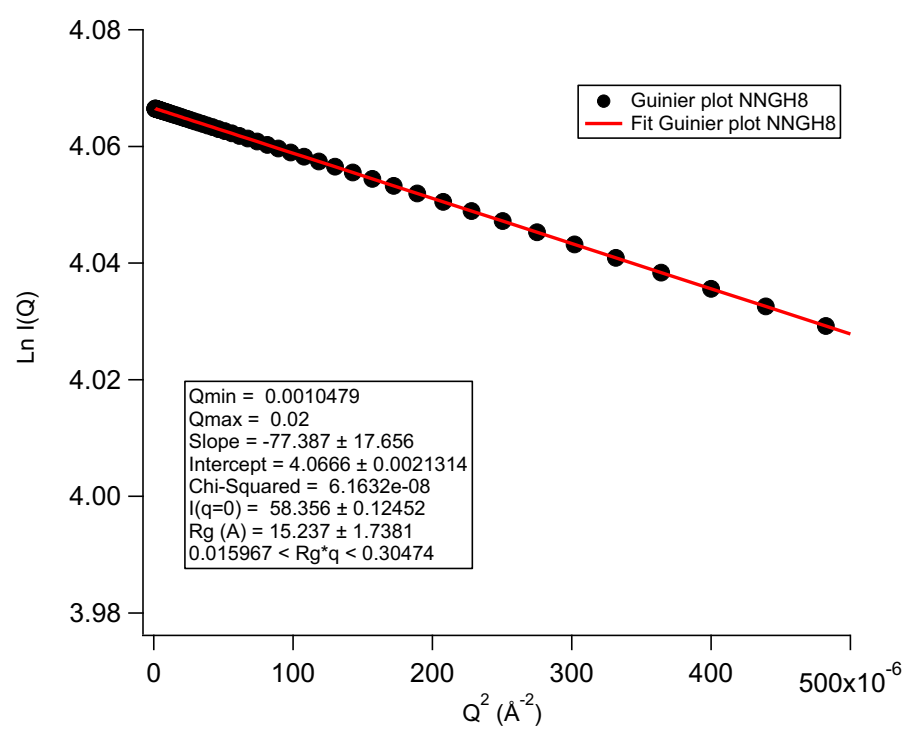


Fig. S4. Guinier plot for sample MMP_NNGH

Fig. S5. Guinier plot for sample MMP_3

\section{References and Notes}

S1 S. R. Kline, Journal of Applied Crystallography, 2006, 39, 895-900.

S2 "Misbehaving proteins. Protein (Mis)Folding, Aggregation, and Stability" Edited by Regina Murphy, Amos Tsai. Springer 2006.

S3 O. Spalla, General theorems in small-angle scattering. In Neutrons, X-Rays and Light: Scattering Methods Applied to Soft Condensed Matter. Lindner and Zemb, North-Holland, Elsevier edition, 2002. 